disease" from the systematisation of ear diseases, inasmuch as these symptoms are the result of so many diverse diseased conditions.

Macleod Yearsley.

\title{
REVIEW.
}

From Cloud to Sunshine. By Alfred S. GubB, M.D., D.P.H., of Algiers and Aix-les-Bains. Pp. 50. Price 1s. Published by Baillière, Tindall \& Cox, London, 1905.

Under this picturesquely descriptive title Dr. Gubb has brought together the siliem fillis il life in Algiers from the point of view of climate. Apart from its excellence as a refuge from the harshness of the northern winter, the climate of Algiers has, of course, certain therapeutical bearings, and these the author has summarised in the pages before us. It is certainly a noteworthy fact that although the European population comprises a large proportion who have taken up their residence in Algiers on account of what may be generically described as weakness of the chest, yet the phthisical death-rate is but a fraction of that of any large city in northern, indeed, even in southern, Europe. An instance is mentioned of a young doctor who, thirty years ago, went to live in Algiers, suffering from advanced laryngeal tuberculosis that had already invaded the larynx and destroyed the vocal cords, yet he lived to become senior physician to the large general hospital at Mustapha and only died a few months since. Apart from chest affections the mild, equable climate is, of course, beneficial in cardiac and chronic renal cases, and in general whenever constitutional or acquired debility renders persons more than usually susceptible to sudden changes of temperature and moisture. The thermometric charts show that there is much greater difference between the climates of Algiers and Nice, for instance, than between Nice and Paris, the average temperature being several degrees higher in Algiers all the year round. The book is prettily got up and tastefully illustrated. Incidentally the various means of getting to Algeria are given together with some sound advice in regard to the choice of a dwelling-house, which no doubt will be appreciated by practitioners who are called upon to advise as to the choice of a winter resort.

\section{BOOKS RECEIYED.}

Transactions of the Twenty-seventh Annual Meeting of the American Laryngological Association. New York: 1905.

P. Lacroix, M.D. Précis de Laryngologie Clinique et Therapeutique. Paris : F. R. de Rudeval. 1906.

Professor A. Onodi. Die Nebenhöhlen der Nase. Narh phntnrryphisorn aufnahmen 124 präparate in naturlicher grösze $. i, 1 \%$ W 11. Alfred Hölder. 1905.

Professor A. Politzer-Dr. Gustav Brühl. Grundriss und Atlas der Ohrenheilkunde. Zweite, umgearbeitete und erweiterte auflage. München: J. F. Lehmann. 1905. 


\section{INDEX TO TOLUME XX, 1905.}

Abductor paralysis (right, unilateral) associated with other paralyses on right side ( $\mathrm{H}$. Tilley)

A BerCROMBIE (P. H.), case of leukoplakia (tongue) . . . 198

- case of lrmpiln-sirerma of the frontal sinuses, with microscopic

report by Dr: Wrill Winrian. . .

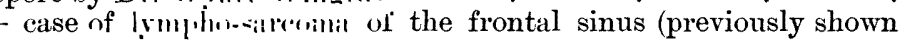
by Dr. Wy lie)

patient shown at previous meeting on whom an operation was performed for adhesion of the soft palate to the pharyngeal wall

- case of epithelioma of the larynx; thyrotomy performed on April 19,1905 case of sarcoma of the frontal sinus.

Abscess (extra-dural), complicated by abscess of neck (Frement) (intervertebro-digastric) (C. Goris) .

(mastoid) five weeks after measles, operation; recovery (L. A. Lawrence)

(sub-periosteal), complicating periostitis of temporal bone

(A. Pugnat) $\quad \therefore$. of antrum of Highmore, simulated by inflamed dentigerous cyst

(W. H. Haskin) of brain, acute (A. L. Whitehead) following on acute otitis media

(P. H. Halsted) limptomitology, diagnosis, and treatment (F. L. Jack). of cereleillum following' acute disease of middle ear (William C. Bull)

$$
\text { (intra-cranial), with basal meningitis (T. H. Pinder) }
$$

- (retro-pharyngeal) of auricular origin; erosion of carotid; death from hamorrhage (F. Klug) :

Adeno-carcinoma occupying all the sinuses, nose, and orbits (W. H.

Dudley)
Adenoid vegetations of pharynx (C. W. M. Brown)
"Adenoids" (1904), (Wyatt Wingrave: review)

post-nasal, specimen removed from man aged fifty-nine $(\dot{H}$.

Lambert Lack)

Adhesion (cicatricial) between soft palate and posterior wall of pharynx, and treatment (J. K. Hamilton)

Air (compressed), local treatment of non-suppurative catarrh of middle ear by compressed air and nebulizer (A. Bronner).$\quad 102$

Air-Compressor, Victor Electrical . . . . . 296 
Air-passages (upper), malignant disease of (Chevalier Jackson)

- malignant growths of (D. Braden Kyle) $\quad \cdot \quad 19$

- syphilitic manifestations in, symposium on $\quad . \quad 609,610$

ALDERTON : some points respecting the surgical anatomy of the facial nerve (abstract)

Algiers (climate of) (Alfred S. Gubb: "From Cloud to Sunshine" review) $\quad 676$

Alreolar lesions: pathogenic role in prolonged acute maxillary sinusitis (Jacquet) .

American Laryngological, Rhinological, and Otological Society : prizes offered by senior members of, for encouragement of special research in diseases of ear, nose, and throat

Ampullary apparatus, demonstration on (W. Stirling) $\quad \begin{array}{cc}16,466,542,604 \\ -\end{array}$

Anæsthesia hemiplegia (secondary), complicating mastoid operation (W. G. B. Harland) . . (local) for aural operations, with special reference to $\mathrm{Dr}$.

Neumann's method (B. Seymour Jones and J. Stoddart Barr) 423, 430

Anastomosis of facial nerve : technique of operation (Villar) . $\quad . \quad 56$ vascular intra-tympanic growth, probably an aneurysm by (T. H. Pinder)

Anatomical anomalies (two) encountered in living subjects duiring performance of mastoid operations (Wm. C. Braislin)

Anatomy of child's ear (S. Bryant)

Aneurysm, thoracic, pulsating, with fixation of left rocal cord (H. $\mathbf{J}$. Davis)

- vascular intra-tympanic growth, probably aneurysm by anastomosis (T. H. Pinder)

Angeiolipoma of right auricle and meatus (P. M. Yeaisley) $\quad \cdot \quad$. $\quad . \quad 256$

\begin{tabular}{llll} 
Angeioma of larynx (C. J. Symonds) & $\cdot$ & & 337 \\
\hline
\end{tabular}

of palate (H. Lambert Lack)

Angeio-neurotic cedema, case of (O. B. Douglas)

374.388

Angina and diphtheria, collargol as a local application in (Justi) . 165

Angina Ludovici, salivary calculus simulating (Wyatt Wingrave) $\quad 38$

Antitoxin treatment of diphtheria; history (A. K. Yost) . 398

- with plea for rational dosage in treatment (B. F. Roger) 352

Antrum (maxillary), abscess of antrum of Highmore simulated by inflamed dentigerous cyst (W. H. Haskin)

- (maxillary), disease of, cystic (Wyatt Wingrave)

490

42

29

- empyema of antrum of Highmore (so-called) in infants

(A. Brown-Kelly) epithelioma, case occurring in boy, excision of superior maxilla for (S. Lodge)

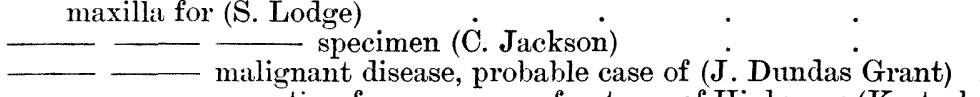

mann) operation for empyema of antrum of Highmore (Kretsch-

mann)

operations by maxillary route for combined disease of maxillary antrum, ethmoid labyrinth, and sphenoid sinus (T. P. Berens) series of $\dot{250}$ temporal bones sectioned vertically through antrum and mastoid process (A. H. Cheatle) (left), permanent opening made from inferior meatus of 166 339 nose into left antrum in case of multiple sinus suppuration (C. Nourse)

(right), new growth of, in boy aged ten (G. C. Catheart) .

Anzinger (F. P.), three cases of croup due to staphylococcus and requiring tracheotomy (abstract) 
Arsenic, great benefit derived from, in lymphosarcoma of tonsil (H. Tilley) .

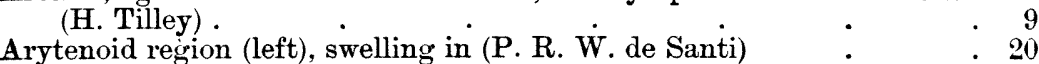
Arytenoid (right) : epithelioma of right arytenoid and adjacent parts removed by lateral pharyngotomy $(H$. Lambert Lack)

Aspiration, treatment of nasal suppuration in children by (Sonderman Asthma in relation to intra-nasal disease (G. MacDonald) 217 (S. West). Atrinson (Dr.) : remarks on Dr. Dundas Grant's case of exostosis of the auditory meatus .

Atomiser for spraying medicated fluid vaseline (Sir F. Semon) $\quad \cdot \quad 37$

Atresia of meatus (H. Macnaughton-Jones) . $\quad . \quad$. $\quad 262$ of left auditory meatus, with deformity of auricle (W. H. Kelson) 151

Auricle, epithelioma of (A. Wylie) growth of (V. W. Wingrave) malformation of, in infant aged three months (V.W. Wingrave) neoplasm of (fibroma ?) (V. W. Wingrave) (left) deformity of, with atresia of left auditory meatus (W. H. Kelson) . enlargement of, and mitral stenosis, associated with complete paralysis of left vocal cord (A. Thorne) (right) and meatus, angeiolipoma (:) of (P. M. Yearslej) sarcoma (giant-celled) of (S. Szenes) .

BABER (E. Cresswell), discussion on case of recurrent ulceration of tonsils associated with lymphadenoma .

discussion on functional and organic paresis of larynx in singer . discussion on primary sore of tongue

BACON (Graham), a report of two cases of acute otitis media suppurativa followed by mastoiditis and meningitis, and caused by the Diplococcus intracelluluris of Weichselbaum (abstract)

BALL (J. B.), discussion on case of fixation of left vocal cord, with pulsating thoracic aneurysm .

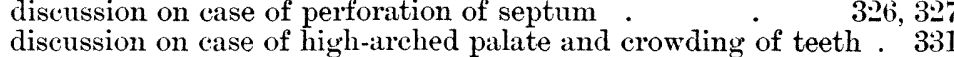

Ballance (Charles), discussion on case of fatal lepto-meningitis - discussion on case of serere tinnitus, with almost complete loss of hearing.

discussion on restoration of hearing after removal of drum and ossicles by a modification of the radical operation for suppurative ear disease.

- discussion on ligature of jugular vein in disease of ear .

Ballenger (William L.), discussion on the relation of diseases of the stomach to affections of the mouth, nose, and throat discussion on case of angeio-neurotic œdema.

BARK (John), remarks on occasion of retiring from presidency of
British Laryngological, Rhinclogical, and Otological Association discussion on salivary calculus simulating angina Ludovici

discussion on case of epithelioma of the laryngo-pharynx wearing a Jacques' œsophageal tube discussion on case of multiple sinus suppuration in which a permanent opening had been made from the inferior meatus of the nose into the left antrum

- discussion on case of excision of superior maxilla for epithelioma of antrum in a boy.

discussion on growth (papilloma) in larynx, under treatment by galvano-cautery 
BARR (J. Stoddart), local anæsthesia for aural operations, with special reference to Dr. Neumann's method

BARR (Thomas), discussion on case of fatal leptomeningitis

discussion on local treatment of some forms of non-suppurative catarrh of middle ear by compressed air and nebulise

- discussion on Ménière's disease

presidential address delivered before the Otological Society of

the United Kingdom on the institution of research work and a permanent museum in connection with the Society

- discussion on restoration of hearing after removal of drum and ossicles by a modification of the radical operation for suppurative ear disease

discussion on supervention of acute labyrinthine suppuration in

case of chronic suppurative otorrhœa .

- discussion on deafness following mumps

- discussion on vertigo opening remarks at Manchester meeting of Otological Society of the United Kingdom

- discussion on sudden and simultaneous onset of cephalic bruit and deafness

discussion on ligature of jugular vein in disease of ear.

BARstow (D. M.), a case of supposed primary tuberculosis of the pharyngeal tonsil (abstract)

BARWELL (Harold S.), two cases of tubercular laryngitis healed under treatment .

- discussion on laryngeal case for diagnosis

case of nasal tuberculosis

- case of lupus of the larynx and uvula

- discussion on case of new growth in right maxillary antrum of

boy aged ten discussion on case of extensive infiltration of pharynx .

the choice of the method of treatment in cases of tuberculous laryngitis, with a plea for the routine inspection of the throats of consumptive patients

— discussion on the treatment of laryngeal tuberculosis . discussion on case of immobile left cord

Basedow's disease : see Goitre (exophthalmic).

BAUMGARTEN (Egmont), hæmatoma of nasal septum, its complication and treatment (abstract)

BeALE (E. Clifford), discussion on tuberculosis of larynx commencing during fifth pregnancy - discussion on case of recurrent ulceration of tonsils associated with lymphadenoma

BECK (Joseph C.), discussion on use of collodium after nose operations .

Belgian Otological, Laryngological, and Rhinological Society, announcement of annual meeting

BenNeTt (F. W.), a case of post-pharyngeal swelling, shown at May Meeting

- photograph of malignant growth of the larynx

discussion on the treatment of laryngeal tuberculosis .
Berens (T. Passmore), results of operations by way of the maxillary route for combined disease of the maxillary antrum, the ethmoid labyrinth, and the sphenoid sinus

discussion on diseases of the accessory sinuses

Biniodide of mercury in cure of acute syphilitic laryngeal stenosis

(M. P. Malafosse)
Bismuth : Röntgen-ray photograph showing pouch when filled witb bismuth in case of pharyngeal diverticulum opening into pyriform fossa (J. Dundas Grant) 
BLAKE (C. J.). vertigo of aural causation (abstract) .

Blood-clot: bealing of eavity by, in case of tympano-mastoid exentera-

tion (F. B. Sprague).
Blood-vessels. distribution of, in labyrinth of ear of sheep and calf (G. E. Shambaugh) .

BonaIN : two cases of stenosis of larynx, etc. (abstract)

Bond (J. W.), discussion on tuberculosis of larynx commencing during fifth pregnancy discussion on case of mass of malignant glands in neck

Bone cysts in accessory sinuses of nose (A. Logan Turner)

Bone (frontal) osteomyelitis, subacute, with empyema of right frontal sinus (R. H. Scanes Spicer)

Bony occlusion of choanz (T. K. Hamilton) of left nostril, almost complete (J. Donelan)

BORDET and LIARAS, treatment of ozæna by high-frequency currents (abstract) .

Borobenphene .

Botelta (Dr.). discussion on case of epithelioma of larynx; treated by laryngo-fissure

Brady (A. J.), peculiar accident to a singer:

Brain : abscess of (acute) (A. L. Whitehead) media (T. H. Halsted)

BraIsLIN (William C.), a case of mastoiditis in an infant, aged one year and a half, with a sequestrum consisting of a large segment of the petrous portion of the right temporal bone; removal of the sequestrum and stapes: recovery (alstract)

two anatomical anomalies encountered in living subjects during the performance of mastoid operations (abstract)

Brandegen (W. P.). report of a case of double mastoiditis with extensive incolvement of the zygomatic cells (abstract)

Breathing: see Mouth-breathing.

Bright's disease: otitis media hæmorrhagica in male patient suffering from gramular kidney and diabetes (W. Milligan)

BrINDEL, preliminary note on treatment of spasmodic coryza by inter-

stitial mjections of paraffin (abstract) ${ }^{2}$ and MovRE. five hundred cases of operation on the mastoid apophysis (abstract).

British Laryngological, Rhinological, and Otological Association: Annual General Meeting meeting of March 10th, 1905 presidential address at General Meeting, January 13th, $190 \dot{5}$ (W. Chichele Nourse) at General Meeting, January 13th, 1905 . 187

$\overline{\text { British Medical Association. serenty-second Annual Meeting }} \begin{aligned} & 179,339, \\ & \text { (1904), }\end{aligned}$ Section of Laryngology and Otology . 102, 159, 217

seventy-third Annual Meeting (1905) Section of Laryngology, Rhinology, and Otology

British physicians and surgeons, visit to Paris (Section of Laryngology and Otology)

BroEckHART (Jules), the operation of election for exposure of the superior orifice of the larynx; sub-hyoid pharyngotomy, with temporary resection of the body of the hyoid bone (abstract) . 
Bronchus (left), obstruction of, by shoe-button (W. B. Thistle)

BRONNER (Adolph), crusts from a case of dry catarrh of the nose and naso-pharynx treated by formalin spray

- on the local treatment of some forms of non-suppurative catarih of middle ear by compressed air and nebulizer . - discussion on Ménière's disease

- discussion on diffuse papilloma of rocal cords

- discussion on squamous-celled carcinoma, first thought to be tubercular.

discussion on the treatment of laryngeal tuberculosis :

Brown (C. W. M.), adenoid vegetations of the pharynx (abstract)

Brown ( $F$. Price), the uses of rubber in the treatment of nasal and antral diseases

a second note on cases of sarcoma of the nose

Brown-KelLY (A.), on the so-called empyema of the antrum of High-

more in infants (abstract)
Bruit (cephalic) and deafness, sudden and simultaneous onset of (P.

BryaN (J. H.), discussion on abuses in intra-nasal surgery . . $13:$

BRYANT (W. S.), tinnitus aurium and its treatment. collodion: its use when the membrana tympani and malleal ligaments are relaxed

- tinnitus aurium and hallucinations of hearing: or the relation of ear disease to auditory hallucinations of the insane

the anatomy of the child's ear, emphasizing points of practical importance (abstract)

BcLI. (William C.), a case of cerebellar abscess following acute disease of the middle ear

Calculus, salivary, simulating angina Ludorici (Wyatt Wingrave)

Calf, distribution of blood-vessels in labyrinth of ear of (G. E. Shambaugh)

CampberL (Colin), discussion on Ménière's disease discussion on intra-nasal disease as a determining factor in production of laryngeal and pulmonary affections

CAMPBELL (Harry), discussion on nasal obstruction and mouth-lreathing

Camphor: "tabloid" quinines camphor, and aconite .

Canal (semicircular external), removal of, with part of cochlea, and external wall of vestibule, for tinnitus and rertigo ( $R$. Lake)

Cancer. mass of malignant glands in neck, swelling of larynx (P. R. W. de Santi) .

of larynx. surgical treatment (V. Cheval)

of tonsils, tongue, and jaws, operated on in Massachusetts General Hospital, 189:-1960 (F. Cobb and C. C. Simmons)

- see also Maligmant disease.

CARBone (A.), a contribution to the study of ocular affections of nasal origin (abstract)

Carcinoma of larynx (W. Jobson Horne) (S. E. Solly)

of nose (H. Lambert Lack)

(squamous-celled) in larynx, first thought to be tuhercular (P. R. W. de Santi) .

Carotid, erosion of, in case of retro-pharyngeal abscess; death from hæmorrhage ( $\mathrm{F}$. Klug)

Carotids, visible pulsation in case of atrophic rhinitis and pharyngitis (J. Donelan)

Carson (H. W.), case of lupus of pharynx and larynx

Catarrh (non-suppurative) of middle ear, local treatment of, by compressed air and nebulizer (A. Bronner).

\section{7 \\ 103 \\ 108 \\ 272 \\ 275 \\ 6.5 \\ 293 \\ 29 \\ 416 \\ $16 i^{\circ}$ \\ 16}

354

$4 \times 5$

$5166^{\circ}$

251

38

504

108

227

34.5

$4(1)$

25

281

672

349

52

$3 \geq 8$

474

9.5

274

237

374

100

103 
Catarrh of nose and naso-pharynx (dry) treated by formalin spray (Adolph Bronner) .

CATHCART (G. C.), case of chronic laryngitis in a male aged thirty-two . combined functional and organic paresis of larynx in a singer aged thirty-four

case of curious multiple growths in the epiglottic region in a man aged forty-three case of new growth in the right maxillary antrum in a boy aged ten

Cauterisation of lower turbinate, nitimate results (J. L. Goodale)

Cells (ethmoidal), orbital and meningeal infection from (J. F. McCaw) . posterior, empyema of, associated with complete occlusion of right posterior naris (R. H. Craigr)

Cephalic bruit and deafness, sudden and simultaneous onset of $(P$.

McBride)
Cerehellum (abscess of), following acute disease of midale ear (William C. Bull) with basal meningitis (T. H. Pinder) .

hernia cerebri et cerebelli. result of acute encephalitis (H. Tod).

Cerebro-spinal rhinorrhcea : see Rhinor hor (cerebro-spinal).

Chalk: piece of blue chalk impacted in respiratory passages for three weeks (H. J. Davis) .

Chavanne (F.), the employment of collodion in cases of relaxation of the memlirane tympani (alistract)

Cheatle (Arthur H.), discussion on case of fatal leptomeningitis notes of case of internal ear deafness of sudden onset.

a few notes on 250 temporal homes of all ages sectioned vertically through the antrum and mastoid process

- discussion on tumour (enrlothelioma) of external auditory meatus discussion on cerebellar abscess following acute disease of midale ear

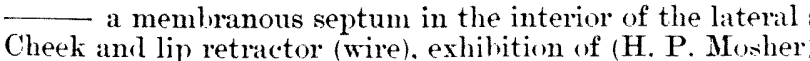
- epithelioma of palate, tonsil, tongue, and cheek (H. FitzGerald Powell)

Cheval (V.), the surgical treatment of cancer of the larynx (alstract) .

CHIARI (Professor), discussion on pharyngo-laryngeal epithelioma

- discussion on case of soft fibroma of larynx and neck. discussion on case of incrustation in trachea .

Child. ear of : anatomy (S. Bryant)

Childhood, operative treatment of diseases of ear in (E. B. Dench)

Children, deafness in, importance of slight dergrees of (G. King) otitis (acute) in. a stuly of fifty-one operative cases in private practice (C. G. Kerley) otitis media in (A. Jacoli) . papilloma of larynx in (J. P. Clark).

Choanæ, hony occlusion of (T. K. Hamilton)

Cholesteatoma (voluminous) (R. Claoue)

Claove (R.), two cases of voluminous cholesteatoma (ahstract)

Clark (Joseph Payson), discussion on diseases of the aecessory sinuses papilloma of the larynx in children (abstract)

COAkLEY (Cornelius G.), discussion on abuses in intra-nasal surgery frontal sinusitis, diagnosis, treatment, and results

two cases of frontal sinus disease operated on by his method

(H. P. Mosher)

COBB (F. C.), maligmant growths of the nose and naso-pharynx
Constion on diseases of the accessory sinuses discussion on the relation of diseases of the stomach to affections of the mouth, nose, and throat presidential address at annual meeting of American Laryngo- 
Coвb (Farrar) and Simmons (Channing C.), the results in cases of cancer of the tonsils, tongue, and jaws, operated on at the Massachusetts General Hospital during the eight years from Jan. 1, 189:2, to Jan. 1, 1900 (abstract)

Cochlea, removal of part of. and external wall of vestibule, and of external semicircular canal for relief of tinnitus and vertigo (R. Lake) .

Codmax (A. S.), a method of rhinoplasty illustrated by plastic operation for rodent ulcer on the face (abstract) .

Coffin (Lewis A.), discussion on case of angeio-neurotic œdema

- the external operation for the relief of ethmoiditis.

Collargol as a local application in angina and diphtheria (Justi)

Collier (Mayo), discussion on case of excision of superior maxilla for epithelioma of antrum in a boy

discussion on nasal obstruction and mouth-breathing .

- exhibition of patient. a man aged fifty-six, on whom he had operated for malignant disease of the tongue.

a case of disease of the ear following a fracture of the base a case of stenosis of the trachea from adenomata in the thyroid.

Collodion in treatment of cases of relaxation of membrana tympani

(F. Chavanne)
use in relaxation of membrana tympani and malleal ligaments

(W. S. Bryant)

use of after nose operations (Kaspar Peschel)
Congress of Medicine, Fifteenth International, to be held at Lisbon

Consumptive patients, routine inspection of throats of, advocated $(\mathrm{H} . \mathrm{S}$. Barwell) .

ConwIN (Theodore W.). discussion on serum treatment of hay fever

Coryza (spasmodic), treatment of, by interstitial injections of paraffin (Brindel)

Cотт (George $\mathbf{F}$.). seven intra-cranial operations within a year.

Craig (Robert H.), papilloma of the larynx, high tracheotomy, thyro-

tomy, recovery (abstract) associated with complete occlusion of right posterior naris (abstract)

combined empyema of the left frontal and ethmoidal cavities (abstract) .

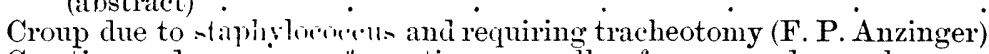

Crusting and mure-pu- formation on walls of naso- and oro-pharynx, accompanied by obstinate headache (L. H. Pegler)

Culp (John F.), discussion on case of angeio-neuretic cedema .

CUMBERBATCH (A. E.), discussion on emphysema? of membrana tympani - discussion on removal of part of cochlea, external wall of restibule, and external semicireular canal for relief of tinnitus and vertigo $\begin{array}{cc}\text { notes on a case of fatal lepto-meningitis following upon acute } & \\ \text { suppurative otitis media of influenzal origin } & .\end{array}$

CURTIS (H. Holbrook), long-standing frontal sinus disease ${ }^{\circ} \quad .490$

Cyst (dentigerous inflamed) simulating abscess of antrum of Highmore

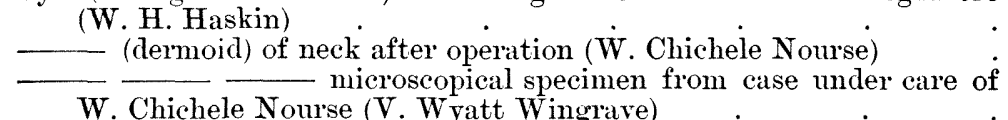

W. Chichele Nourse (V. Wyatt Wingrave)

Cystic disease of antrum ( $V$. W yatt Wingrave)

Cysts of tympanic membrane (R. Haug) .

Davis (H. J.), discussion on fixation of left vocal cord

fixation of left vocal cord in a man aged forty-nine, with a

pulsating thoracic aneurysm . 
Davis (H. J.), traumatic (?) perforation of the septum in a boy aged

seventeen a piece of blue chalk, half an inch in length, impacted for three weeks in the respiratory passages of a boy aged ten case of left facial paralysis (one week); ulceration of oro-and naso-pharynx (five weeks) in a man aged forty-seven

(Ewing W.), discussion on nose and ear complications in diphtheria, scarlatina, and measles acute purulent otitis media complicating typhoid ferer : report of a case, with autopsy

Deafness (almost complete), severe tinnitus with (E. F. Potter) - and cephalic bruit. sudden and simultaneous onset of (P. McBride).

following mumps (R. Lake)

in children, importance of slight degrees of (G. King). sudden and simultaneous onset of cephalic bruit and (P. McBride)

Deformity in case of nasal polypus (V. Wyatt Wingrave)

Delavan (D. Bryson), discussion on abuses in intra-nasal surgery $\quad 133$

Dessaux $(V$.), thrombo-phlebitis of the cavernous sinus of otitic origin (abstract).

$$
\text { eversion or prolapse of ventricle of Morgagni (abstract) }
$$

DENCH (Edward B.), discussion on results of obstruction of Eustachian

tube discussion on intra-cranial complications of middle-ear suppuration

discussion on nose and ear complications in diphtheria, scarlatina, and measles

discussion on indications for operation in acute mastoiditis 548,550

- the operative treatment of diseases of the ear in childhood (abstract).

DENKER (A.), on the treatment of hay ferer (abstract)

Dermoid cyst of neck after operation (W. Chichele Nourse) .

Diabetes and granular kidney in a man with otitis media homorrhagica (W. Milligan)

Diagnosis, cases for : aumal case ( $\dot{W}$. Chichele Nourse) growth on left rocal cord (S. Paget) headache (obstinate) accompanied by crusting and muco-pus

formation (L. H. Pegler) . . . infiltration (extensive) of pharynx with slight ulceration (C. A. Parker)

$$
\text { inspiratory dyspnoa, history of syphilis (P. R. W. de Sianti) }
$$
laryngeal case (P. R. W. de Santi). (W. Chichele Nourse)

malignant disease of maxillary antrum (probably) $(\dot{J}$. Dundas Grant) ulceration (extensive) of nasal septum (F. W. Bennett) - ulceration of palate (V. Wyatt Wingrave)

Diaphragm (cicatricial) due to inherited syphilis passing from posterior third of tongue to posterior wall of pharynx (H. Betham Robinson)

Diphtheria and angina. collargol as a local application in (Justi) . antitoxin treatment, history of (A. K. Yost) . 
Diphtheria in reference to infectivity and notification of latent forms

(P. Watson Williams) innocent cases reported as (H. W. Hill) nasal (F. Massei) nose and ear complications (J. McCollom)

Diplococcus intracellularis of Weichselbaum causing acute otitis media suppurativa in two cases (G. Bacon) of pharynx opening into pyriform fossa (J. Dundas Grant) 317,37

Donelan (James), a case of almost complete bony occlusion of the left nostril, the result of trauma and septal deformity in a man aged twenty-five - a case of atrophic rhinitis and pharyngitis with visible pulsation of the carotids in a man aged thirty-six jecting into naso-pharynx

_ discussion on local treatment of some forms of non-suppurative catarrh of middle ear by compressed air and nebulizer

Dosage (rational) in antitoxin treatment of diphtheria (B. F. Roger)

Dovglas (O. B.), case of angeio-neurotic odema .

Downie (J. Walker), discussion on intra-nasal disease as a determining factor in production of laryngeal and pulmonary affections discussion on case of epithelioma of larynx treated by laryngo-

fissure . wool) (F. Koch) $\cdot$ H.), adeno-carcinoma occupying all of the sinuses, nose, and orbits .

DUEL (Arthur B.), cases illustrating difficulties in the diagnosis of mastoid complications

Duverger, de la voie trans-maxilio-nasale, etc. (abstract)

Dyspnœa, inspiratory, case with history of syphilis (P. R. W. de Santi) .

Ear, abstracts of literature on $\quad . \quad 56,112,167,240,295,350,399,505,564$ disease of, case for diagnosis (W. Chichele Nourse) $\quad 616,67$ following fracture of base of skull (M. Collier).$\quad .44{ }^{\circ}$ for (C. Heath) (suppurative), modification of radical mastoid operation \begin{tabular}{ll} 
(C. Heath) & 86 \\
\hline
\end{tabular} McCollom) complicating diphtheria, scarlatina, and measles $(\vec{J}$. " • . . 542 "Diseases of the Ear" (1904) (J. K. Love, review) : 507 ligature of internal jugular vein for (J. Dundas Grant) . 453 operative treatment of, in childhood (E. B. Dench) : 616 prizes offered for special research in. by senior members

of American Laryngological, Rhinological, and Otological Society. reflex pareses and affections of speech and writing of auricular origin (Pugnat)

disease (W. Milligan) oferative interference in various types of aural retropharyngeal abscess of auricular origin (F. Klug) suction as a therapeutical measure in (Sondermann) of ear disease to auditory hallucinations of the insane (W.S. Bryant) (internal), deafness of. of sudden onset (A. H. Cheatle)

Shambaugh)

of, distribution of blood-vessels in sheep and calf (G. E. middle, disease, acute, cerebellar abscess following (W. C. Bull) . 
Ear, mi ddle, disease, and complications, protracted cases of (A. Wiener) mooted points in treatment of protracted cases

and their complications (A. Wiener) - diseases complicating the exanthemata, operative treatment (A. K. Gordon)

intra-cranial complications, pathological findings

(T. J. Harris)

511,556

482

pressed air and nebulizer (A Bronner) local treatment by com-

103

509

chronic (W. Milligan) hysteria following (S. Szenes)

in (T. Hubbard) chronic : basal meningitis later (T. H. Pinder) . obstruction of Eustachian tube, a factor

Turner) - temporal bones from cases of (A. Logan

reference to Dr. Neumann's method (B. Seymour Jones and J.

Stoddart Barr)

- pathological changes in, in case of unilateral congenital lesion of medulla and spinal cord (P. R. W. de Santi and P. Stewart)

pathology of the infant's ear underlying aural and general

disease (J. A. Kenefick)

some manifestations of influenza in (G. King)

tinnitus of, treatment (W. S. Bryant)

Electrical spray heater.

ELTERICH (T. J.), papillomata of the larynx in an infant (abstract)

Emphysema? of membrana tympani (A. L. Whitehead)

Empyema of antrum of Highmore, operation for (Kretschmann)

of frontal sinus (F. C. Cobb) (so-called) in infants (A. Brown-Kelly).

of frontal sinus (subacute), following scarlet fever $(\mathrm{H}$. Tilley)

of right frontal sinus with subacute osteomyelitis of frontal bone

(R. H. Scanes Spicer)

- of right sphenoidal cavity and posterior ethmoidal cells. associated with complete occlusion of right posterior naris (R. H. Craig)

Empyemata (chronic) of frontal and other nasal accessory sinuses, radical operations for $(\mathrm{H}$. Tilley)

Encephalitis, symptomatology, diagnosis, and treatment (F. L. Jack) : (acute), causing hernia cerebri et cerebelli $(H$. Tod)

Endothelioma, tumour of external auditory meatus (E. B. Waggett)

Epiglottic region, multiple growths in (G. C. Cathcart)

Epiglottis : epithelioma of epiglottis and base of tongue removed by sub-

hyoid pharyngotomy (H. Lambert Lack)
malignant disease of base of tongue and epiglottis (P. R. W.

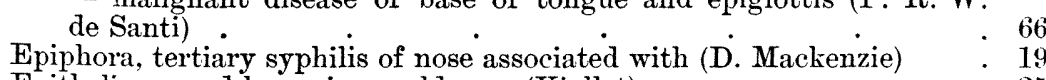

Epithelioma and lupus in an old man (Viollet)

istic of epithelioma (J. Dundas Grant). $\quad .378$ 
Epithelioma of right arytenoid and adjacent parts removed by lateral

pharyngotomy (H. Lambert Lack)

of auricle (A. Wylie)

- of right auricle (S. Szenes)

of epiglottis and base of tongue removed by sub-hyoid pharyn-

gotomy (H. Lambert Lack) of laryngo-pharynx (V. Wyatt Wingrare) $\cdot$ case wearing a Jacques' cesophageal tube (V. Wyatt

Wingrave) . of larynx (H. Smurthwaite)

(V. WyattjWingrave) removal of greater part of (Sir Felix Semon)

Thomson) .

Eruption on fauces (W. H. Kelson)
Escat (T.). Inritimacr of clinical distinction between lupus and ordinary

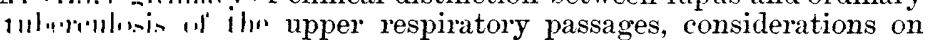
the etiology of lupus (abstract)

Ethmoid cells, orbital infection from, with spontaneous opening of the inner angle of the orbit (C. E. Munger)

necrosis of (W. Hill)

Ethmoiditis, external operation for relief of ${ }^{\circ}\left(\mathrm{r}^{\circ} \mathrm{A}\right.$

Eudrenine

Eustachian cartilages, abnormally large, projecting into naso-pharynx

(E. Furniss Potter) . obstruction, a factor in post-operative mastoid fistulia, and in chronic suppuration of middle ear (T. Hubbard).

Exanthemata, middle-ear complications of, operative treatment (A. K. Gordon)

Exostosis of the auditory meatus (J. Dundas Grant)

Extra-dural abscess complicated by abscess of neck (Frement). oto-ocular reflexes (C. Hennebert) .

Face, rodent ulcer on: method of rhinoplasty illustrated by plastic operation for (A.S. Codman)

Facial nerve: see Nerve (facial).

FagGe (C. H.), discussion on Ménière's disease

discussion on hernia cerebri et cerebelli, the result of acute encephalitis discussion on removal of part of cochlea, external wall of vestibule, and external semicircular canal for relief of tinnitus and vertigo - discussion on cerebellar abscess following acute disease of middle ear

Farrell (Thomas H.), discussion on syphilitic manifestations in upper air-passages

Fauces : abstracts of literature on deformity of (W. H. Kelson) $50,109,165,237,293,349,395$ eruption on (W. H. Kelson) 
Ferran, sequestrum of the wall of the meatus

.$\quad 352$

FERRERI : torticollis following removal of adenoids (abstract). $\quad . \quad 53$

Fibroma (?), neoplasm of auricle (V. W. Wingrave) • $\quad \cdot \quad 263$

- of larynx in child aged three ; tracheotomy, subsequent laryngo-

fissure for removal, and prolonged intubation (T. J. Harris) . 361

- of tongue, specimen (W. H. Kelson) $\quad . \quad 383$

(soft) of larynx and neck removed by operation withont opening cavity of larynx (Sir F. Semon)

Filro-myxomatoid outgrowth on right side opposite middle turbinated body (D. Grant)

Fistula (mastoid) : see Miastoid fistuia.

Fixation of left vocal cord (S. Pagret)

Forceps (laryngeal) for use in direct laryngoscopy (D. R. Paterson)

Foreign bodies in throat (Ramon de la Sota $y$ Lastra)

Foreign body in subglottic region (Gosteau).

Formalin spray : crusts from dry catarh of nose and naso-pharynx treated by (A. Bronner)

Fossa (supra-tonsillar), pedunculated tumour growing from ( $\dot{\mathcal{J}}$. Dundas Grant)

Fox (Clayton), discussion on diffuse papilloma of rocal cords . discussion on case of ulceration of nose and trachea . discussion on laryngeal case for diagnosis $\quad . \quad$. $\quad . \quad 44$

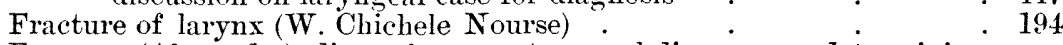

Francis (Alexander), discussion on intra-nasal disease as a determiningr factor in production of laryngeal and pulmonary affections

Frement : extra-dural abscess complicated by abscess of the neck (abstract)

French Society for Laryngology and Otology, entertainment of British medical men at

FreUdenthal (Wolff), discussion on case of angeio-neurotic odema . further experience with radical operations for frontal sinus disease

Galvano-cautery, histological changes brought about in nasal mucous membrane by application of (A. Westerman)

papilloma in larynx under treatment by (A. Wy lie)

Garcra (Senor Manuel), exhilition of illuminated address to be presented to, at meeting of British Laryngological, Rhinological, and Otological Association on March 10. 190.5

Garcia Celebration : programme of erents . in relation to Laryngological Society of Londion
Gauze and wool dressings (renoform) impregnated with suprarenal
extract (F. Koch) .

GELLÉ : adenopathies in affections of the nasal fossæ (abstract)

Glands (malignant) in neck, mass of ; swelling of larynx, same side (P. R. W. de Santi) .

GLÜCK (Professor), discussion on pharyngo-laryngeal epithelioma fissure

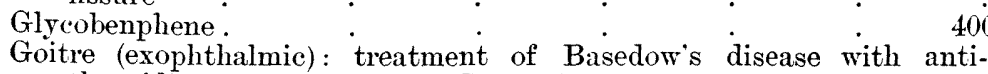
thyroidine serum (Moebius) (Hempel)

Gocostern (M. A.), malignant growths of the mouth and pharynx

Goodale (J. L.), the ultimate results of cauterisation of the lower turbinate, with therapeutic suggestions based on histological findings (abstract).

GorDor (A. Knyrett), some experiences in the operative treatment of the middle-ear complications of the exanthemata 
GorIs (C.), intervertebro-digastric abscess (abstract)

GOSTEAU : foreign body in subglottic region (abstract) . $\quad 166^{2}$

Grant (J. Dundas), case of exostosis of the auditory meatus . 41

discussion on case of fatal leptomeningitis . . . $\quad 73$

- discussion on case of severe timnitus with almost complete loss

of hearing .

discussion on case of internal ear deafness of sudden onset

in a male patient aged twenty-two, the growth of such a size and

shape as at first sight to simulate the mindle turbinated body

discussion on case of chronic laryngitis

case of hypertrophic rhinitis involving both inferior turbinated

bodies (recently cauterised), and fibro-myxomatoid outgrowth on the

right side opposite the middle turbinated hody in a female patient aged twenty-two

case of ulcer of tongue in a boy aged two and a half

- discussion on local treatment of some forms of non-suppurative

catary of middle ear by compressed air and nebuliser.

discussion on Ménière's disease ${ }^{*} \cdot{ }^{-} 104$

discussion on case of mastoid fistula . . . . $\quad 266$

- discussion on case of otitis media hæmorrhagica in man with

granular kidney and diabetes

discussion on diffuse papilloma of vocal cords

case of pharyngeal diverticulum opening into the pyriform fossa

in a woman aged fifty-one, with Röntgen-ray photograph showing

the pouch when filled with hismuth

discussion on case of fixation of left vocal cord, with pulsating

thoracic aneurysm.

discussion on case of perforation of septum .

discussion on case of carcinoma of larynx

discussion on case of broarlening and disfigurement of external

nose due to swellings attached to cartilaginous septum

- discussion on case of olistinate headache accompanied by crust.

ing and muco-pus formation.

discussion on unilateral right abductor paralysis associated with

other paralyses on right side.

discussion on case of hony occlusion of left nostril

discussion on laryngeal case for diagnosis .

case of pharyngeal diverticulum opening into the pyriform fossa

in a woman aged fifty-one

- case of excavated ulcer of the pharynx presenting the punched-

out appearance of a tertiary lesion, but with a desree of induration

characteristic of epitheliona, in a male subject aged sixty.

- discussion on case of left facial paralysis, with ulceration of oro-

and naso-pharynx

discussion on subacute osteomyelitis of frontal bone, with empyema

of right frontal sinus

- discussion on vertigo

some considerations regarding ligature of the internal jugulat

vein on account of ear disease

- discussion on the treatment of laryngeal tuberculosis .

- case for diagnosis. probably malignant disease of the maxillary

antrum

case of a pedunculated tumour, probably cystic, growing from

the supra-tomsillar fossa

- case of diverticulum of the cesophagrus

- case of trammatic lesion of larynx

disconssion on case of immobile left cord

and Nourse (Chichele), retrospect of otology 
GraY (Albert A.), a demonstration of specimens prepared by the author's method to show the membranous labyrinth in man and lower animals - discussion on removal of part of cochlea, external wall of restibule, and external semicircular canal for relief of tinnitus and vertigo

$$
\text { the theories of hearing }
$$

Grossman, notes on cases of lumbar puncture and localised meningitis (abstract) .

Growth of auricle (V. Wratt Wingrave) of tonque (fihroma), specimen (W. H. Kelson) $\quad 383$ on right vocal cord, patient previously operated on for papilloma of larynx (S. Pagret) . removed twenty-two years aro, with present hoarseness, cough. pain. and hoody expectoration (E. Law) (malignant) of larynx, photograph of (F. W. Bennett)

- (new) in right maxillary antrum of boy aged ten (G. C. Catheart) (papilloma) in larynx. under treatment by galvano-cautery (A. Wylie) (vascular intra-tympanic) probably an aneurysm by anastomosis (T. H. Pinfler)

Growths (multiple) in epionltic rewion (G.C. Catheart)

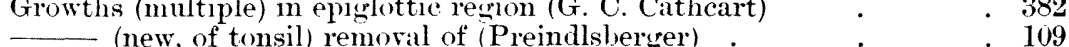

GRCLNWALD (L.), some observations on the treatment of laryngeal tuber('ulosis

GuARNACIA (E.), a new method of treating otomycosis aspergillina (abstract)

GubB (Alfred S.). " From Cloud to Sunshine," 1905 (review) •

GuYE (Professor A. A. G.), olituary

Habershow (S. H.), the treatment of laryngeal tuberculosis. Introduction to a discussion in the Section of Iarrnerolnars. Otology, and Rhinology at the annual meeting of the British Minlical Association. Leicester, 1905

HAEFFNER and HENRICI, do suppumations in the accessory cavities of the nose lring ahout narrowing of the field of vision? (abstract) . 166

Hrmatoma of nasal septum, complications and treatment (E. Baumuarten) 505

HALL (F. de Havilland), discussion on case of lymphosarcoma of tonsil . discussion on case of faucial eruption

discussion on case of complete paralysis of left vocal cord associated with dilatation of left pupil, mitral stenosis, and enlargement of left auricle .

- discussion on case of inspiratory dyspncea with history of syphilis - discussion on case of immobile left cord discussion on case of perverted action of the cord

Hallucinations of hearing and tinnitus aurium, or relation of ear disease to auditory hallucinations of the insane (W. S. Bryant) .

HALSTED (Thomas H.), discussion on case of angeio-neurotic odema . - ahscess in the temporo-sphenoidal lobe of the brain following an acute otitis media ; operation ; recovery

Hamilton (T. K.). bony occlusion of the choana . cicatricial adhesion between the soft palate and the posterior wall of the pharynx and its treatment .

Hammerschlag (V.), the influence of heredity in otosclerosis (abstract)

HARING (N. C.), discussion on intra-nasal disease as a determining factor in production of laryngeal and pulmonary affections

- discussion on the treatment of laryngeal tuberculosis

Harland (W. G. B.), secondary anasthesia hemiplegia as a complication of the mastoid operation (abstract) 
Harmer (L.), contribution to the uses of the cesophagoscope in a case of non-malignant tumour of the cesophagus (abstract)

HARRIS (Thomas J.), discussion on abuses in intra-nasal surgery papilloma of the naso-pharynx simulating epithelioma .

fibroma of the larynx in a child aged three years. necessitatin tracheotomy and subsequent laryngo-fissure for its removal, followed hy prolonged intubation - pathological findings of intra-ceanial complications of middleear disease.

discussion on diseases of the accessory sinuses

HASKIN (William H.), inflamed dentigerous cyst simulating abscess of the antrum of Highmore

HAUG (R.). cysts of tympanic membrane (abstract) $\cdot{ }^{\circ} \quad \cdot$

HAWTHORNE (C. O.), discussion on case of fracture of larynx.

Hay ferer, treatment (A. Denker, Prausnitz) or prevention of (R. Mohr) .

- serum treatment of (H. W. Loeh)

Healache (obstinate) accompanied by crusting and muco-pus formation on walls of naso- and oro-pharynx (L. H. Pegler)

Head-lamp, improved, exhibition of (J.A. Stucky) - modified exhibition of (Wendell C. Phillips) .

Hearing, restoration of. after removal of drum and ossicles (C. Heath)

- theories of (A. A. Gray)

Heart complications in diphtheria (F. H. White and H. H. Smith)

Heдтн (Charles), a short paper (founded upon an experience of 400 operations) on the restoration of hearing after removal of the drum and ossicles by a modification of the radical mastoid operation for suppurative ear disease

discussion on case of fractive of larynx

HefFerman (D. A.), the submucous resection of the nasil septum (abstract).

Hemiplegia, secondary anæsthesia hemiplegia complicating mastoid operation (W. G. B. Harland)

Hespel, contribution to the treatment of Basedow's disease with anti. thyroidine serum (Moebius) (abstract).

Henle (spine of). constancy and rarieties of (P. Macleod Yearsley) .

HENNEBERT (C.), oto-ocular reflexes (abstract)

HenRICI and HAEFfNer, do suppurations in the accessory cavities of the nose bring about narrowing of the field of vision? (abstract)

Heredity in otosclerosis, influence of (V. Hammerschlag)

Hernia cerel,ri et cerehelli, the result of acute encephalitis ( $\mathrm{H}$. Tod)
Hery l,y Dr. Pinkus

High-frequency currents, treatment of ozana by (Liaras and Bardet)

HiLL (G. William), two cases of ethmoidal necrosis. .

_ discussion on vertigo ${ }_{-}$discussion on case of abnormally large Eustachian cartilages projecting into naso-pharynx .

HrL, (H. W.). innocent cases reported as diphtheria (abstract)

Histological changes brought about in the nasal mucous membrane by action of galrano-cautery (A. Westerman)

Holmes (C. R.), discussion on malignant disease of the upper air-passages

Holmes (Edgar M.), discussion on acute purulent otitis media complicating scirlet fever.

Horne (W. Johson), discussion on microscopic specimens of tuberculosis of the faucial tonsil, tuherculosis of the cervical lymph-glands, epithelioma of the laryngo-pharynx

discussion on case of internal ear deafness of sudden onset acute encephalitis 
Horne (W. Jobson), discussion on traumatic perforation of tympanic membrane .

- discussion on intra-nasal disease as a determining factor in production of laryngeal and pulmonary affections .

discussion on case of fixation of left rocal cord, with pulsating thoracic aneurysm.

- a case of carcinoma of the larynx.

discussion on case of broadening and disfigurement of external nose due to swellings attached to cartilaginous septum .

discussion on soft fibroma on left vocal cord.

discussion on laryngeal case for diamosis $\quad \cdot \quad \cdot \quad \cdot \quad \cdot \quad \cdot 3$

- discussion on case of bleeding polypus of septum ${ }_{\text {- }}$ treatment of laryngeal tuberculosis. Introduction to a discus-

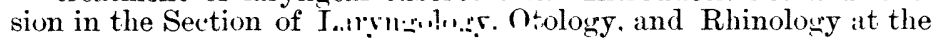

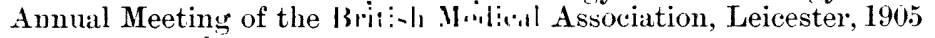
discussion on case of pedunculated tumour growing from supratonsillar fossa discussion on case of perverted action of the cords

discussion on case of perverted action of the cords
Horslenx (Sir Victor), vertigro: an address delivered before the Otolorical Society of the United Kingdom.

HUBBARD (Thomas). obstruction of Eustachian tube a factor in postoperative mastoid fistula and in chronic suppuration of the middle

ear discussion on nose and ear complications in diphtheria, scarlatina, and measles.

Hunt (J. Middlemass), discussion on the treatment of laryngeai tuberculosis

Hurd (Lee M) discussion on diseases of the accessory sinuses $\dot{\circ}^{\circ}$

Hydrorrhoa (nasal) (J. E. Rhodes)
Hyperplasia (subglottic) producing tracheal stenosis, origin probably syphilitic (H. Tilley)

Hysteria following acute middle-ear suppuration (S. Szenes)

PAGE

Incrustations from dry catarrh of nose and naso-pharynx treated by formalin spray (A. Bronner) .

- in trachea (E. Law)

Infant (ear of), anatomy of at times hy

Kenefick)

pathology of, underlying aural and general disease (J.A.

— malformation of auricle in (V. Wyatt Wingrave) .

- mastoiditis in. operation, recovery (W. C. Braislin)

Infants: empyema of antrum of Highmore (so-called) in (A. BrownKelly) (newly-born) mastoid operations in (Lamens)

Infection of orbit from ethmoid cells with spontaneous opening of the inner angle of the orbit (C. E. Munger)

Infectivity of diphtheria, and notification of latent forms ( $\dot{\mathrm{P}}$. Watson Williams)

Infiltration of pharynx, extensive, with slight ulceration (C. A. Parker).

Inflammation of tympanic cavity, acute septic; treatment (A. H. Young and W. Milligan)

Influenza, manifestations of, in ear and upper air passages (G. King) . origin of acute suppurative otitis media, causing fatal leptomeningitis (A. E. Cumberbatch) 
INGals (E. Fletcher), discussion on carcinoma of larynx $\quad . \quad$ PAGF a new operation and instruments for draining the frontal sinus . 489

Inhaler (new), designed by Dr. Heryng, of Warsaw (Dr. Pinkus) . 374

Injections, intra-laryngeal, syringe for (V. Wyatt Wingrave) . $\quad .46$

Insane, relation of ear disease to auditory hallucinations of (W. S.

\begin{tabular}{ccccc} 
Bryant) & $\cdot$ & $\cdot$ &. & 485 \\
Instruments, exhibition of (C. Jackson) & $\cdot$ & $\cdot$ &. &. \\
\hline
\end{tabular}

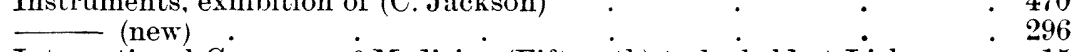

International Congress of Medicine (Fifteenth) to be held at Lisbon $\quad . \quad 15$

Intervertebro-digastric abscess (C. Goris) . . . . . 674

Intra-cranial abscess, cerebellar, with basal meningitis (T. H. Pinder) • 500

complications of middle-ear diseases; pathological findings (T. J.

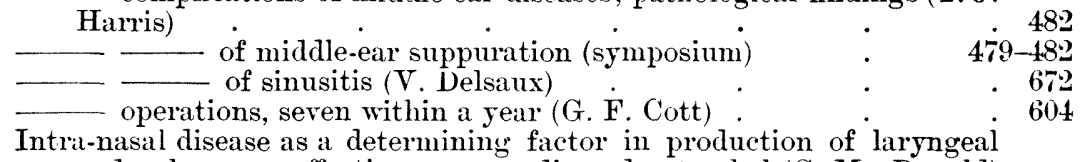

Intra-nasal disease as a determining factor in production of laryngeal and pulmonary affections, spasmodic and catarrhal (G. MacDonald)

\section{(S. West)}

217,236

Intubation and tracheotomy, relative value (Schiffers) $\quad . \quad$. $\quad 673$

- (prolonered) after tracheotomy and laryngo-fissure for removal of fihruna "f larynx (T. J. Harris)

Italian Society of Laryngology, Rhinology, and Otology, Ninth Congress

JACK (Frederick L.), symptomatology, diagnosis, and treatment of encephalitis and brain abscess

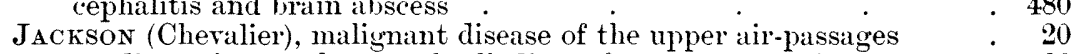

discussion on the use of collodium after nose operations $\quad . \quad 32$

- presentation of instruments . . . . 470

exhibition of specimens : (1) of epithelioma of the larynx, (2) of epithelioma of the antrum, (3) of epithelioma of the larynx $\quad 473$

- discussion on carcinoma of larynx . $\quad . \quad 475$

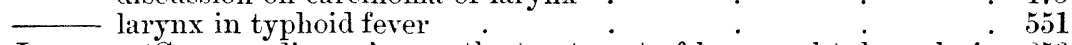

JAckson (George), discussion on the treatment of laryngeal tuberculosis 659

$\begin{array}{lcc}\text { J ACoBr (A.), otitis media in children (abstract) } & . & 616\end{array}$

JAcques: the pathogenic role of alveolar lesions in prolonged acute maxillary sinusitis (abstract).

Jacques asophageal tuhe: case of epithelioma of laryngo-pharynx

wearing $(\mathrm{V}$. Wyatt Wingrave)
Jaws, cancer of, results of cases operated on in Massachusetts General Hospital, 1892-1900 (F. Cobb and C. C. Simmons) . . 349

Johnston (Samuel), discussion on abuses in intra-nasal surgery $\quad . \quad 134$

Jones (B. Seymour), local anæsthesia for aural operations, with special reference to Dr. Neumann's method

Jones (Hugh E.), discussion on case of fatal leptomeningitis .

discussion on supervention of acute labyrinthine suppuration in case of chronic suppurative otorrhoa

- discussion on cerebellar abscess following acute disease of middle ear

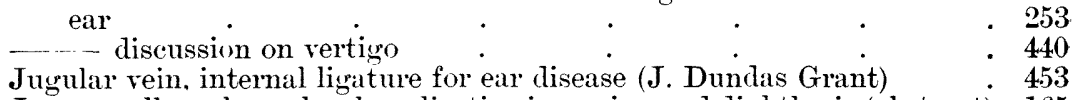

JUSTI : collargol as a local application in angina and diphtheria (abstract) 165

KELsON (W. H.), case of papilloma of the larynx _ . $\quad$. $\quad 38$ discussion on case of epithelioma of the laryngo-pharynx wearing

a Jacques' cesophageal tube.

atresia of left anditory meatus and deformity of auricle 
KELSON (W. H), case of nasal polypus with deformity pagr discussion on case of fracture of larynx $\quad . \quad$. 194 discussion on case of paralysis of left vocal cord following operation for adenoids a case of lingual growth in a man aged sixty. - discussion on case of high-arched palate and crowding of teeth : - case of laryngeal disease greatly improved after nasal treatment - case of deformity of the fances

- discussion on growth (papilloma) under treatment by galvanocautery case of faucial eruption.

a specimen of a lingual growth

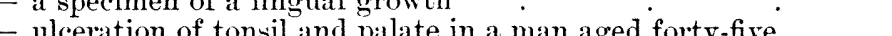

ulceration of tonsil and palate in a man aged forty-five

KENEFICK (Joseph A.), the pathology of the infant's ear underlying aural and general disease

KERLEY (C. G.), acute otitis in children; a study of fifty-one operative cases in private practice (abstract)

KERRIson (Philip D.), indications for operation in acute mastoiditis

Kidney (granular) and dialsetes, in a man with otitis media hæmorrhagica (W. Milligan)

Killian's inspection of trachea and osophagus : demonstration (H. P. Mosher)

Killian's method, submucous resection of deflected nasal septum by $\left(\mathrm{H}^{\circ}\right.$. Tilley)

KING (Gordon), some manifestations of influenza in the ear and upper. air-passaces (ahistract)

the importance of slight degree of deafness in children (abstract)

KLUG (Ferdinand), ret ripharrmenil alucess of auricular origin; erosion of carntid; death from himorrhirg. twenty-four hours after opening the alssess (ahstract)

KNAPP (Arnold), discussion on orbital infection from ethmoid cells, with spontaneous opening of inner angle of orbit - ase of infective thrombosis of the sirmoid and lateral sinuses after acute mastoiditis; death from meningitis ; autopsy, report.

Kocu (F.), the therapentic use of dressings impregnated with suprarenal extract (renoform gauze and wool) (abstract)

Konig (Professor). discussion on case of fixation of left rocal cord, with pulsating thoracic aneurysm .

Kretschmans, contribution to the operation for empyema of the antrum of Highmore (abstract)

KYLE (D. Braden), the pathology of malignant growths of the upper air-passages

Labyrinth (aural) of sheep and calf, distribution of blood-ressels in (G. E. Shambaugh)

- (ethmoid), combined disease of ethmoid lahyrinth, maxillary antrum, and sphenoid sinus, operation by maxillary route for (T. P.

Berens) (membranous) in man and lower animals, demonstrated by specimens (A. A. Gray) . . . . . . . . .

- reception of sound in (Mongardi, "Considerations et analogies physiques ") physiques")
suppuration in: operation in two cases; special reference to path
of infection (W. Milligan) rhe (H Tille. supervening in case of chronic suppurative otor-

rhœa (H. Tilley) . . . . . $\quad 147$

LACK (H. Lambert). case of bony tumour of the nose $\quad \cdot \quad \cdot \quad 94$ 
LACK (H. Lambert), discussion on case of lymphosarcoma of tonsil . discussion on case of lupus of pharynx and larynx.$\quad 101$

- discussion on tuberculosis of larynx commencing during fifth pregnancy .

discussion on squamous-celled carcinoma first thought to be

tubercular.

- discussion on case of recurrent ulceration of tonsils associated

with lymphadenoma.

case 1, epithelioma of epiglottis and base of tongue removed by

subhyoid pharyngotomy

- case 2 , ep hithelioma of right arytenoid and adjacent parts removed

by lateral pharyngotomy

case of high-arched palate and crowding of teeth due to nasal

obstruction, showing the factors producing the deformity

- a c ase of angeioma of the palate

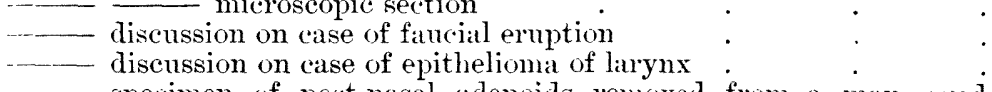

- specimen of post-nasal adenoids removed from a man aged

fifty-nine - discussion on case of malignant disease of base of tongue and

epirlottis .

LAKE (Richard), discussion on case of severe timnitus, with almost com-

plete loss of hearing.

- oto-masseur driven by a turbine (Ash) $\quad$.

- notes on two cases of deafness following mumps

encephalitis

- case of removal of part of the cochlea, external wall of the

vestibule, and of the external semicircular canal for relief of timnitus

and vertigo

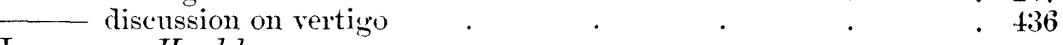

Lamp: see Head-lamp.

Laryngitis, chronic, ease of (G. C. Catheart) _ . $\quad .99$

(tubercular) two cases healed under treatment (H. S. Barwell) : 323

- treatment; choice of method (H. S. Barwell) .

Laryngo-fissure after tracheotomy in removal of fibroma of larynx (T. J.

Harris) . . . . . 361

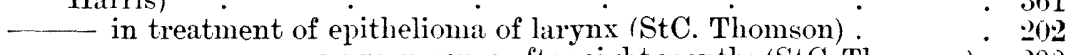

- - no recurrence after eight months (StC. Thomson). 290

Laryngological Society of London: Garcia celebration in relation to . 283

- proceedings report of Morbid Growths Committee . . . 201

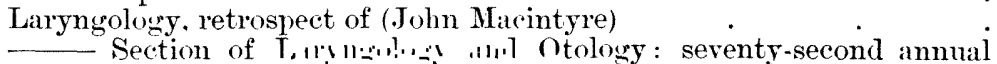
meeting British $.1 \cdots, \ldots i c, 1, \ldots \ldots \ldots$ - Section of Laryngology, Rlimilny. ani ntology : seventy-third

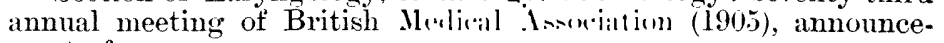
ment of programme .

Section of Laryngology and Otology at visit of British physi-

cians and surgeons to Paris

Laryngo-pharynx, epithelioma of (V. Wyatt Wingrave)

Wingme case wearing Jacques' œsophageal tube (V. Wyatt

Wingrave) . $\quad \cdot \quad \cdot \quad \cdot 39$

Laryngoscopy (direct). laryngeal forceps for use in (D. R. Paterson) $\quad 212$

Larynx, ahstracts of literature on . $\quad 56,111.166,239,294,396,672$

- and neck, soft fibroma of, removed by operation without opening

(avity of larynx (Sir F. Semon)

- angeioma of (C. J. Symonds) $\quad . \quad: \quad: \quad: 337$ 
Larynx and neck, drawing of (StC. Thomson)

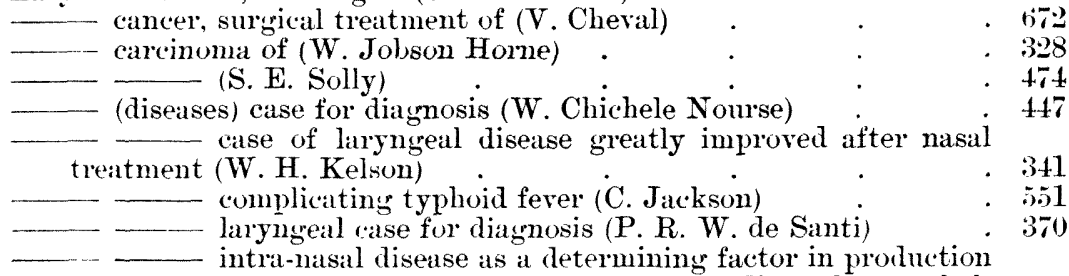

of laryngeal and pulmonary affections (spasmodic and catarrhal)

(G. MacDonald)

(S. West) · · $\quad 217,230$ paintings in oil illustrating (H. Smurthwaite) . . . 212

epithelioma of (H. Smurthwaite) . 384

Tricroscopical specimen of case under care of Dr. Lodge

(V. Wratt Wingrave) . . 344

- pharyngo-laryngeal (P. R. W. de Santi) : : 286

ב- removal of ireater part (Sir F. Semon) $: 48$

- thyrotomy for (P. H. Alererombie) : $\quad \cdot \quad \cdot 4.5$

treated by laryngu-fissure (StC. Thomson)

sem)

) $\cdot$.

290

290

381

- case shown seven years after (C. J. Symonds) . 367

- filroma, in child aged three, tracheotomy, subsequent laryngo-

fissure for removal, prolonged intubation ( $\mathrm{T}$. J. Harris) .

opening cavity of larynx (Sir F. Semon)

fracture of (W. Chichele Nourse)

inflammatory cedema of obscure origin affecting posterior parts

(Sir F. Semon) . . intrinsic laryngeal neoplasm of left vocal cord $(R . \dot{H}$. Scanes

Spicer) lupus of larynx and uvula (H. S. Barwell) : $\quad \cdot \quad \cdot 38$ of pharynx and larynx (H. W. Carson) . $\quad .100$ (primary) of larynx and pharynx (StC. Thomson) . 314 malignant growth of ( $F$. W. Bennett) $\quad .279$ nystagmus. (\%) in case of tumour of pons (Sir F. Semon)

operation for exposure of superior orifice of larynx; subhyoid

pharyngotony, with temporary resection of hyoid bone (J. Broeck-

$\begin{array}{cccc}\text { hart) } & \cdot \\ - \text { papilloma of (W. H. Kelson) } & \cdot & \cdot & \cdot \\ \text { (C. J. Symonds) } & \cdot & \cdot & \cdot\end{array}$

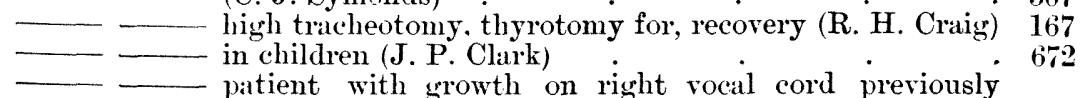

operated on for (S. Paget) papillowata of. in an infant (T. J. Elterich) . $\quad . \quad 111$ paresis of, combined functional and organic, in a singer (G. C.

Catheart). . . . . . . 281 stenosis, treatment by tracheotomy (StC. Thomson) : $\quad 203$ - two cases (Bonain)

(Malafosse) swelling of, on same side as mass of malignant glands in neck

(P. R. W. de Santi). 
Larynx swelling thought to be tubercular, later shown to be squamouscelled carcinoma (P. R. W. de Santi). unusual case requiring tracheotomy (C. F. Theisen) syphilitic manifestations in (F. B. Packard) syringe for intra-laryngeal injections (V. Wyatt Wingrave) traumatic lesion of (J. Dundas Grant) tuberculosis, case of (W. Chichele Nourse)
in woman, commencing during tifth pregnancy

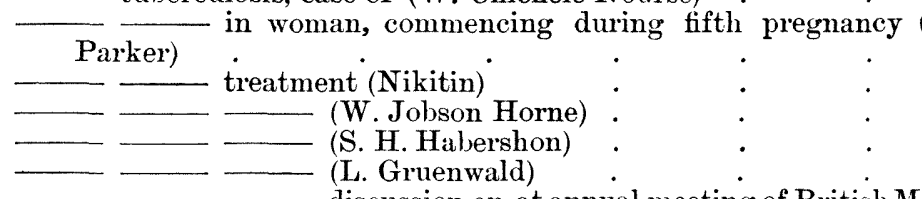

Association (1905) (L. Gruenwald)

discussion on case of severe tinnitus, with almost complete loss

of hearing .

discussion on urticaria of the drum .

hoarseness, cough, pain, little bloody expectoration, man aged sixty-nine from whom the late Dr. Whistler removed a growth from the right rocal cord twenty-two years ago

- a case of incrustrations in the trachea, with, at times, well-marked stenosis

LAwRENCE (L. A.) : "urticaria of the drum"
notes of a case of mastoid abscess five weeks after measles; operation; recovery.

Leland (George A.). discussion on nose and ear complications in

diphtheria, scarlatina, and measles
Lepto-meningitis (fatal) following acute suppurative otitis media of
influenzal origin (A. E Cumberbatch) influenzal origin (A. E. Cumberbatch) with infective sigmoid sinus and jugular thrombosis (J. D. Richards).

Leukoplakia of tongue (P. H. Alererombie)
LEVY (Robert), the relation of diseases of the stomach to affections of the mouth, nose, and throat .

LIARAS and BARDET, treatment of ozwna by high-frequency currents (abstract) .

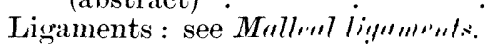

Ligature of internal juyulitr win for ear disease (J. Dundas Grant)

Lip retractor : see Cheek and lip retractor.

LoDGE (Samuel), case of excision of superior maxilla for epithelioma of antrum in a boy

- microscopical specimen of epithelioma of larynx from case under care of Dr. Wyatt Wingrave ..

LOEB (H. W.), discussion on carcinoma of larynx discussion on diseases of the accessory sinuses $\quad \cdot \quad \cdot 476$ the serum treatment of hay fever $\quad . \quad 604,608$

LogaN (J. E.), discussion on the uses of rubber in the treatment of nasal and antral diseases . $. \quad . \quad . \quad . \quad 30$

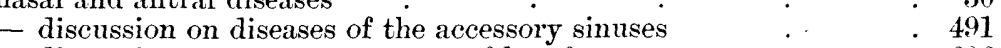

- discussion on serum treatment of hay fever . $\quad . \quad 506$

syphilis of the nose and accessory sinuses . $\quad . \quad 609,610$

- discussion on abscess in temporo-sphenoidal lobe of brain follow-

ing an acute otitis media . $\quad . \quad 612$ 
Love (J Kerr) "Diseases of the Ear" 1904 (review) discussion on ligature of jugular vein in disease of ear.

discussion on continuity of the several cavities of niddle ear. on their development, and on treatment of acute septic inflammation of tympanic eavity (so-called otitis media)

Lumbar puncture and localised meningitis (Grossman) plicated by leptomeningitis (J. D. Richards)

Lumgs (diseases), intra-nasal disease as a determining factor in production of laryngeal and pulmonary affections (spasmodic and catarrhal) (G. Macdonald)

LunN (J. R.), and Thorne (Atwood), case of epithelioma of the nose (shown at the January meeting. 1904); patient, macroscopic and microscopic specimens and photographs

Lupus, etiology of (E. Escat)

of larynx and pharynx (primary) (StC. Thomson)

and urula (H. S. Barwell)

of pharynx and larynx (H. W. Carson)

(of upper respiratory passages), legitimacy of clinical distinction between lupus and ordinary tuberculosis of upper respiratory passages (E. Escat)

Lymphadenoma, recurrent ulceration of tonsils associated with (F. J. Steward) .

Lymph-glands (cerrical), tubereulosis of (V. Wyatt Wingrave)

Lympho-sarcoma of frontal sinus (A. Wylie. P. H. Abercrombie) of frontal sinuses (P. H. Abercrombie) of tonsil greatly benefited by arsenic (H. Tilles)

McBride (P.). discussion on case of lympho-sarcoma of tonsil _ 98

- discussion on case of chronic laryngitis . $\quad . \quad 500$

discussion on case of lupus of pharynx and larrnx $\quad: \quad .100$

- sudden and simultaneous onset of cephalic bruit and deafness

$\mathrm{McCAw}$ (J. F.), mastoiditis . . . 27

discussion on nose and ear complications in diphtheria. scarla. tina, and measles . . . . . . - discussion on acute purulent otitis media complicating scarlet fever orbital and meningeal infection from ethmoid cells .

McCollom (John), nose and ear complications in diphtheria. scarlatina. and measles

MacDonatd (Greville), introluctory paper of discussion on intra-nasal disease as a determining factor in the production of laryngeal and pulmonary affections (spasmodic and catarrhal) .

(reply)

Macinty Re (John), retrospect of liaryngology

Mackenzie (Dan), case of tertiary syphilis of the nose, associated with epiphora .

Mackenzie (John N.). remarks on some abuses in the intri-nasil surgery of to-day

McKernon (James F.), symptomatology, diagnosis and treatment of sigmoid sinus thrombosis

Macnaughton-Jones (H.), discussion on case of severe timnitus, with almost complete loss of hearing 
Macnatghton-Jones (H.), discussion on restoration of hearing after removal of drum and oesicles by a modification of the radical operation for suppurative ear disease

drawing of a traumatic perforation of the tympanic membrane . 157

- discussion on angeiolipoma (5) of right amicle and meatus . 2.57

- case of atresia of meatus. . . . 262

- liscussion on operative treatment of middle-ear complications of the exanthemata.

Malafosse (M. P.), a case of acute syphilitic laryngeal stenosis: cure by injection of hiniodide of mercury (abstract)

Malformation of auricle in infant aged three months (V. W. Wingrave)

Malignant disease of upper air-passages (Chevalier Jackson) .

- of maxillary antrum, probable case of (J. Dundas Grant)

- of pharyngro-larynx, slides from case of (C. J. Symonds) of tongue, arse operated on (M. Collier)

of lase of tongue and epiglottis : question of operation (P. R. W. de Santi)

Maligmant glands in neck, mass of ; swelling of larginx same side $(P . R$. TV. de Santi)

Malisnant growth of larynx, photograph of (F. W. Bennett) .

Maligmant growths of unper air-passages; pathology (D. Braden Kyle) . of mouth (M. A. Goldstein)

_ of nose and maso-pharynx (F. C. Colb)

- _ of pharynx (M. A. Goldstein)

Malloal ligaments, use of collodion in relaxation of (W. S. Bryant)

Manchester. Extra-Metropolitan meeting of Otological Society of the United Kingdom at.

Massachusetts General Hospital, results of cases of cancer of tonsils, tongue. and jaws operated on at (1892-1900) (F. Cobl) and C. C. Simmons).

Masser (F.), nasal diphtheria (abstract)

Masseur (new) for the ear (Sondermamn)

Mastoid aliscess five weeks after measles; operation; recovery (L. A. Lawrence)

(A. (sub-periosteal) complicating periostitis of temporal bone

(A. Pugnat) apophysis, five humdred cases of operation on (Mome and Brindel

- complications, cases illustrating difficulties in diagnosis of

(A. B. Duel)

- - pest-operative: obstruction of Enstachian tube a factor

in (T. Hubliard) operation complicated $\dot{b y}$ secondary anasthesia hemiplegra

(W. G. B. Harland) .

(radical) for suppmative ear disease (C. Heath) operations in the newly-born (Laurens)

two anatomical anomalies encomtered in living subjects

luring performance of (Wm. C. Braislin)

- process: series of 250 temporal bones sectioned vertically

through antrum and mastoid process (A. H. Cheatle) .

Mastoiditis (J. F. MeCaw)

- (acute) followed hy infective thrombosis of sigmoid and lateral sinuses (A. Knapp) . operation in. indications for (P. D. Kerrison) . and meningitis following in two cases of acute otitis media suppurativa (G. Bacon) .

- (double) extensive involvement of zygomatic cells (W. P.

Brandegee)

- in an infant; operation; recovery (Wm. C. Braislin) . 
Matheson (Farquhar), obituary notice

PAGE

Maxilla (superior), excision, for epithelioma of antrum in a boy (S. Lodge)

Maxillary route, results of operations by way of for combined disease of maxillary antrum, the ethmoid labyrinth. and the sphenoid sinus (J. P. Berens)

MAYER (Emil), discussion on abuses in intra-nasal surgery

Measles, mastoid abscess five weeks after (L. A. Lawrence)

- nose and ear complications (J. McCollom)

Meatus, atresia of (H. Macnanghton-Jones)

- sequestrum of wall of (Ferran)

auditory, exostosis of (J. Dundas Grant)

Medulla and spinal cord, unilateral congenital lesion of pathological changes in mouth, throat, and ear (P. R. W. de Sinti and P. Stewart)

Ménièrès disease: see vètigo (amral).

Ménière symptom-complex (the) (W. A. Lecompte)

Meninges, orbital and meningeal infection from ethmoid cells (J. F. I.Caw)

Meningitis and mastoiditis following in two cases of acute otitis media suppurativa (G. Bacon) Pinder)

\section{in case of alsseess of cerehellum (T. H. Pinter)}

death from. following infective thrombosis of sigmoid and lateral simuses after acute mastoiditis (A. Knapp)

symptomatology. diagnosis, and treatment, with report of case

(S. MacCuen Smith)

- see also Lepto-meningitis.

Mentharenal, therapentic preparation

Mercury : see Biniodide of mercury.

Mral (L. L.), discussion on indications for operation in acute mastoiditis

Microphotographs, demonstration of series of (W. Millinan)
Microscopic specimens, collection to he formed hy Brish Larrngological, Rhinological, and Otological Association: Dr. Wyatt Wingrave appointed custodian

MuLLIGan (William), retrospect of rhinology discussion on case of fatal lepto-meningitis

discussion on case of serere timnitus, with almost complete loss of hearing . discussion on local treatment of some forms of non-suppurative
catarrh of middle ear hy compressed air and nebulizer - Ménièrès disease, a clinical and experimental inquiry.

- discussion on restoration of hearing after removal of drum and ussicles by a modification of the radical operation for suppurative ear disease.

- _ two cases of labyrinthine suppuration recently operated on, with special reference to the path of infection

- discussion on supervention of acute labyrinthine suppuration in case of chronic suppurative otorrhœa

- discussion on hernia cerebri et cerebelli, the result of acute encephalitis discussion on angeiolipoma (?) of right auricle and meatus discussion on case of atresia of meatus 
Mrlutgas (William), discussion on neoplasm of auricle ( 2 fibroma) discussion on case of mastoid fistula

notes on a case of otitis media hremorrhagica in a male patient suffering from granular kidney and diabetes

series of microphotographs

epitome of cases to illustrate the results of operative interference in various types of amal and nasal disease

the lines of treatment in preventing acute middle-ear suppuration from becoming chronic

and Young (A. H.), the continuity of the several cavities of the middle ear, with ohservations on their development, and on the treatment of acute septic inflammation of the tympanic cavity (so-called otitis media)

Mitral stenosis and enlargement of left auricle associated with complete paralysis of left rocal cord (A Thorne) .

Moebius's anti-thyroidine treatment of Basedow's disease (Hempel, Thienger) .

Möller (Iorgen). some remarks on a case of otosclerosis, with autopsy (abstract) .

MoHR (R.), the treatment or prevention of hay fever (ahstract)

Molinie: obliteration of pharyngeal opening of Eustachian tube (abstract) .

Mongardr : considerations et analogies physiques [transmission of sound in middle ear and its reception in labyrinth] (abstract) .

Morbid Growths Committee of Laryngological Society of London, report of

Mosher (H. P), exhibition of new instruments : (1) a wire cheek and lip retractor, (2) a safety pin closer for use in the osophagus and trachea. (3) a nasal splint - demonstration of Killian's inspection of the trachea and cosophagus exhibition of two cases of frontal sinus disease that had been

\section{discussion on diseases of the accessory sinuses}

the applied anatumy of the frontal sinus (abstract)

Moure (E. J.) discussion on pharyngo-laryngeal epithelioma . $\quad .286$ - and BRINDEL: five hundred cases of operation on the mastoid apophysis (abstract)

Mouret : recent inrestigations on the cells of the petrous bone (abstract). . . . . thrombo-phlebitis of the latemal sinus (abstract) . . .

Mouth (diseases): diseases of stomach in relation to ( $R$. Lery) $\quad$. 32 - malignant growths of (M. A. Goldstein) . . 18 pathological changes in, in case of unilateral congenital lesion of medulla and spinal cord (P. R. W. de Santi and P. Stewart)

Mouth-breathing and nasal obstruction (J. Sim Wallace) . 179, 345

Muco-pus formation and crusting of walls of naso- and oro-pharynx, accompanied hy obstinate headache (L. H. Pegler)

Mucous memhrane (nasal) : see Nose, mucous memlirane of.

Mumps, leafness following (R. Lake)

Muncer (Carl E.), orlitial infection from the ethmoir cells, with spontaneous opening of the inner angle of the orbit .

Museum : sumgester formation of permanent museum in connection with Otolurical Suciety of the United Kingrom (T. Barr: presidential arlitress)

Mycosis in upper respiratory tract, etiology and treatment of $(\mathrm{J}$. Sendziak)

Mrers (Henry L.), discussion on case of angeio-neurotic cedema

MyLes (R. C.). diseases of the salivary ducts and glands and their treatment 
Mrles (R. C.), discussion on the uses of rubber in the treatment of nasal and antral diseases

PAGE

Nasal splint, exhibition of (H. P. Mosher) . • . . . . . 472

Naso-pharynx, abnormally large Eustachian cartilages projecting into

(E. Furniss Potter)

catarrh of (dry), treated by formalin spray (Adolph Bronner) : $\quad 47$

crusting and muco-pus formation on walls of, accompanied by

olstinate headache (L. H. Pegler)

malignant growths of (F. C. Cobb)

papilloma of, simulating epithelioma (T. J. Harris)

(H. J. Davis)

Nebulizer, de Vilhiss Nebulizer

- local treatment of non-suppurative catarrh of middle ear by compressed air and nebulizer (A. Bronner)

Neck, alsceess of, complicating extra-dural abscess (Frément) . . $\quad 675$

- and larynx, fibroma of (soft), removed by operation without opening carity of larynx (Sir F. Semon) dermoid cyst of, after operation (W. Chichele Nourse) .

specimen shown by V. Wyatt Wingrave

(P. R. W. de Santi) .

Necrosis (ethmoidal) (W. Hill)

Neoplasm of auricle (fibroma ?) (V. W. Wingrave) . $\quad . \quad 263$

$\longrightarrow$ (intrinsic laryngeal) of left vocal cord (R. H. Scanes Spicer) . 391

Nerve (facial) anastomosis : technique of operation (Villar) . $\quad \mathbf{5 6}$

- some points respecting surgical anatomy of (Allerton) . 350

Nerves (recurrent laryngeal), bilateral paralysis of (L. Revol). . $\quad 294$

Neumann's method of local anasthesia for aural operations (B. Seymour Jones and J. Stoddart Barr) .

Newcomb (Dr.), discussion on intra-nasal disease as a determining factor in production of laryngeal and pulmonary affections . . 235

Nikitin : the treatment of laryngeal tuberculosis (abstract) . $\quad$. $\quad 239$

Nose. ahstracts of literature on - $\quad 52,110,165,238,293,395,505,613,670$ abuses in intra-nasal surgery of present time (J. M. Mackenzie) . 120

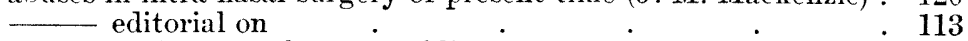
accessory sinuses; abstracts of literature on

5.) $110,165,395,613,670$ adeno-carcinoma occupying all of the sinuses, nose, and orbits (W. H. Dudley) . . . . . $\quad 26$ chronic empyemata of frontal and other nasal accessory sinuses (H. Tilley)

\begin{tabular}{lrr}
- & & $486-497$ \\
\hline intra-nasal route in operating upon (W. A. Wells) & 487 \\
\hline pathology of bone cysts in ( $\mathrm{A}$. Logan Twner) & 53
\end{tabular}

vision? (Henrici and Haeffner) adeno-carcinoma in all the sinuses, nose, and orbits (W. H.

Dudley)

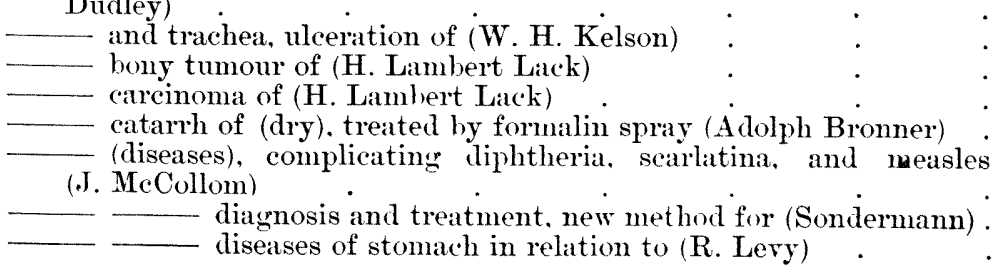


Nose (diseases), insufficiently known disease of nasal origin (R. Stevani) prizes offered for special research in. hy senior members

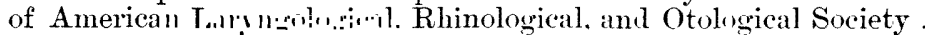
disease (W. Milligan)

disease (W. Milligan)
uses of rubber in treatment of (Price Brown)
(external), broadening and disfigurement cansed hy tense.
bilateral. non-vascular swellings attached to anterior third of car.

tilaginous septum (L. H. Pegler)

- (fossæ) : adenopathies in affections of (Gellé) .

(W. A. Wells)

malignant growths of (F. $\dot{\text { C. Cobb) }}$.

mucous membrane of, histological changes in. due to application

of galvano-cautery (A. Westerman) nasal obstruction and mouth-breathing (J. Sim Wallace) 179. 345

(H. Lambert Lack) complete, due to tense bilateral non-vascular swellings

attached to anterior third of cartilaginous septum (L. H. Pegler) .

- nasal suppuration in children; treatment ly aspiration (Sonderiuann)

- nasal treatment greatly benefiting case of laryngeal disease

(W. H. Kelson)

- ocular affections of nasal origin (A. Carbone).

operations upon : fatal results of (F. R. Pachard) : use of collodium after (Kaspar Pischel)

permanent opening marle from inferior nieatus of nose into left

antrum in case of multiple sinus suppuration (C. Nourse)

- polypus, with deformity (W.H. Kelson)

sarcoma of (J. Price Brown)

(septum) bleeding polypus of, in boy aged nine (E. B. Wargett)

- (deflected), submucous resection (Killian's method) $(\mathbf{H}$.

Tilley) deformity causing almost complete bony occlusion of left

nostril (J. Donelan).

- hæmatoma of, complications and treatment (E. Baum-

(rarten) hypertrophic rhinitis with sessile outgrowth on (D. Grant) infiltration of left side of cartilaginous septum nasi

(C. A. Parker) sarcomatous growth of left nasal cavity (attached to septum) (P. R. W. de Santi) . submucous resection of (D. A. Heffernan) traumatic (:) perforation of (H. J. Daris) ulceration of (extensive) (F. W. Bennett)

syphilis, tertiary, associated with epiphora (D. Mackenzie)

tuberculosis of (H. S. Barwell)

ulcer of (primary) (Wyatt Wingrave)

Nostril (left), bony occlusion, almost complete: result of trauma and septal deformity (J. Donelan)

(right posterior), empyema of right sphenoidal cavity and posterior ethmoidal cells associated with complete occlusion of (R. H. Craig)

Notification of latent forms of diphtheria, and infectivity of $(\dot{\mathrm{P}}$. Watson Williams) .

Nourse (W. Chichele), case of multiple sinus suppuration on which a permanent opening had been made from the inferior meatus of the nose into the left antrum 
Nourse (W. Chichele), case of maxillary sinusitis for which the radical operation had been performed - aural case for diagnosis

- discussion on restoration of hearing after remoral of drum and ossicles by a modification of the radical operation for suppurative ear disease.

earesidential address at General Meeting of British Laryngological, Otological, and Rhinological Association (Jamuary 13, 1905)

- discussion on tertiary syphilis of nose associated with epiphora. - case of fracture of the larynx in a man aged sixty-five .

case of paralysis of the left rocal cord following operation for adenoids in a young woman aged twenty

- specimen of rhinolith

dermoid cyst of neck. microscopical specimen shown by

V. Wyatt Wingrare

- discussion on sulacute osteomyelitis of frontal bone with empyema of richt frontal sinus

a laryngeal case for diagnosis ${ }_{-}$exhibition of a case of dermoid cyst of the neck after operation

exhibition of a case of laryngeal tuberculosis in a woman aged twenty-six . discussion on prevalence of adenoids
discussion on lipature of jugular vein in disease of ear.
and Grant ( $\mathrm{J}$. Dumdas), retrospect of otology
Nystagmus. pharyngeal and laryngeal, in catse of $(\cdot)$ tumour of pons (Sir
F. Semon).

PAGE

Obituary: Guye. Professor A. A. G.

Esophageal tube (Jicques'), case of epithelioma of larynx wearing

(V. Wyatt Wingrare) . . .

Esophagoscope, use of, in a case of non-malignant tumour of cesophayus

(L. Harmer)

Esenhogins abstracts of literature on

C. copharns. alistracts of literature on $\quad \cdot \quad 350,615$ liverticulum of (.J. Dundas Grant) : $\quad . \quad$. $\quad 664$

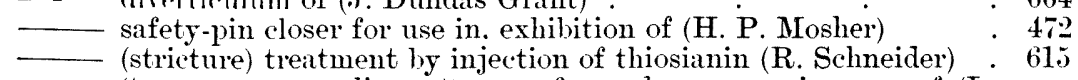

(tumour, non-malignant) use of osophagoscope in case of (L.

Harmer) . . . . . 350

ONODI (Professor), presentation of plates illustrating anatomy of frontal and other sinuses . $\quad . \quad 325$

Orbit: infection of. from ethmoid cells, with spontaneous opening at inner angle of orbit (C. E. Munger).$\quad 26$

Orbital and meningeal infection from ethmoid cells (J. F. Mc $\dot{C a w}) \cdot 612$

Orbits : adeno-carcinoma in all the sinuses, nose, and orbits (W. H. Dudley) . . . . . . . .

Oro-pharynx : crusting and muco-pus formation on walls of accompanied by obstinate headiche (L. H. Pegler)
ulceration of oro- and naso-pharynx. with left facial paralysis (H. J. Davis) of and naso-pharynx. with left facial paralysis

Ossicles. restoration of hearing after removal of drum and ossicles by modification of radical mastoid operation (C. Heath).$\quad 86$

Osteoma in right external auditory meatus (S. Szenes).$\quad 518$

Osteomyelitis, subacute, of right frontal bone, with empyema of right frontal sinus (R. H. Scanes Spicer) 
Otitis (acute) in children : study of fifty-one operative cases in private practice (C. S. Kerley)

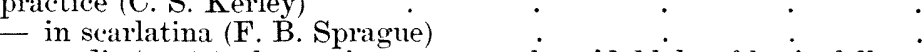
media (acute), abscess in temporo-sphenoidal lobe of brain following (T. H. Halsted)

(acute purulent) complicating typhoid fever; case with autopsy (E. W. Day)

acute septic inflammation of tympanic cavity (so-called otitis media) (A. H. Young and W. Milligan)

- (acute suppurative) of influenzal origin, causing fatal lepto-meningitis (A. E. Cumberbatch) .

(W. Milligan) hæmorrhagica in man with granular kidney and diabetes in children (A. Jacoli)

itis, eansed prativa, two cases followed by mastoiditis and meningritis, caused by Diplococcus intracelluluris of Weichselbaum (G. Bacon)

- thrombo-phlebitis of cavernous sinus of otitic origin (V. Delsaux)

Otocysts, demonstration on (W. Stirling)

Otological Society of United Kingdom, annual meeting and annual dinner institution of research work and permanent museum in connection with (T. Barr: presidential address). proceedings of

Risien Russell extra-metropolitan meeting held at Manchester addresses on vertigo by $\mathrm{Sir} \dot{\mathrm{V}}$. Horsley and Dr. 403,409

Otology, retrospect of (Dundas Grant and Chichele Nourse)
section of Laryngology and Otology, at visit of British physicians and surgeons to Paris - section of Laryngology and Otology, seventy-second annual meeting of British Medical Association (1904). proceedings 102, 159, 217 - section of Laryngology, Rhinology, and Otology. seventy-third annual meeting of British Medical Association (1905), announcement of programme.

Oto-masseur driven by a turbine (Ash) (R. Lake) : . . $\quad .82$

Otomycosis aspergillina: new method of treatment (E. Guarnacia) $\quad . \quad 53$

Oto-ocular reflexes (C. Hennebert) . . . . 690

Otorrhcea, suppurative. chronic, supervention of acute labyrinthine suppuration in case of $(\mathrm{H}$. Tilley) $\quad . \quad$. $\quad .147$

Otosclerosis, influence of heredity in (V. Hammerschlag) : $\quad: 673$

$\begin{array}{lll}\text { - with autopsy (T. Möller) . } & 619\end{array}$

Outgrowth (sessile) on septum, in hypertrophic rhinitis (D. Grant) . 94

Ozæna, etiology and diagnosis, and relation to pulmonary tubereulosis

(C. F. Theisen) $\quad 165$

new surgical treatment for stubborn cases of (J. Broeckaert) $\quad . \quad 613$

PACKARD (F. R.), a study of the fatal results of operations upon the nose $\begin{array}{ll}\text { and throat (abstract) } & 165 \\ \text { discussion on indications for operation in acute mastoiditis } & \cdot 550\end{array}$

syphilitic manifestations in the larynx and trachea $\quad .609$

PAGET (Stephen), fixation of the left vocal cord in a man aged about forty . . - growth on the right rocal corl in a woman who had undergone operation twelve years previously for papilloma of the larynx wrowth on the left vocal cord in a man aged forty-six, who had 
Palate, angeioma of ( $\mathrm{H}$. Lambert Lack)

epithelioma of palate, tonsi:, tongue, and cheek (H. FitzGerald

Powell)

(high-arched) and crowding of teeth due to nasal obstruction $\left(\mathrm{H}^{\circ}\right.$

Lambert Lack)

(soft), adhesion between posterior wall of pharynx and (T. K.

Hamilton) .

.

patient previously shown (P. H. Abercrombie)

\begin{tabular}{l} 
alceration ; case for diagnosis (F. H. Westmacott) \\
\hline
\end{tabular} of tonsil and palate (W. H. Kelson).

Papilloma of larynx (W. H. Kelson) (C. J. Symonds) $\quad: \quad: \quad 567$

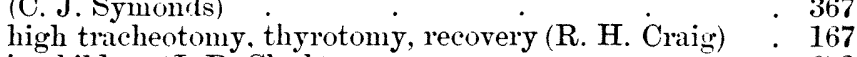
in children (J. P. Clark) . . . 672 patient with growth on right vocal cord previously

operated on for (S. Paget) . . . $\quad 277$ - under treatment by galvano-cautery (A. Wylie) $\quad: 343$ of naso-pharynx simulating epithelioma (T. J. Harris) $\quad . \quad 359$ of rocal cords (diffuse) (F. Spicer : shown by C. Fox) . : 271

Papillomata of larynx in an infant ('T. J. Elterich) . : 111

1 treatment of spasmodic coryza by interstitial injections of (Brindel) 111

Paraffin (injections of), histological research upon (Broeckaert) . 671

Paralysis (bilateral) of recurrent laryngeal nerves (L. Revol) . $\quad .294$

- (facial, left) with ulceration of oro- and naso-pharynx (H. J. Davis) $\mathbf{3 7 7}$

- of left vocal cord, caused by localised tumour of thyroid gland:

malignant? (F. J. Steward) complete, associated with dilatation of left pupil, mitral stenosis, and enlargement of left auricle (A. Thorne) $\quad .387$ following operation for adenoids (W. Chichele Nourse) $\quad . \quad 386$ (unilateral right abductor), associated with other paralyses on right side $(\mathrm{H}$. Tilley)

Paresis of larynx (combined functional and organic) in a singer (G. C. Catheart) .

- (reflex) of auricular origin (Pugnat)

Paris : risit of British physicians and surgeons to Paris (Section of

Laryngology and Otology) .
PARKER (C. A.). discussion on case of tracheal obstruction case of thickening of the external plates of the thyroid cartilage and infiltration of the left side of the cartilaginous septum nasi case of tuberculosis of the larynx in a woman aged thirty-one, which commenced during her fifth pregnancy, and since which there have been four subsequent pregnancies
case of extensive infiltration of the pharynx, with slight ulceration; for diurmosis

Paterson (D. R.), laryngeal forceps for use in direct laryngoscopy
Pegrer (L. Hemington), discussion on local treatment of some forms of

non-suppurative catarth by compressed air and nebulizer
discussion on restoration of hearing after removal of drum and ossicles by a modification of the radical operation for suppurative ear clisease .

_ discnssion on case of pharyngeal and laryngeal nystagmus .

- discussion on case of ulceration of soft palate duction of laryngeal and pulmonary affections. discussion on functional and organic paresis of larynx in singer. case of broadening and disfigurement of the external nose caused by tense. bilateral, non-vascular swellings attached to the anterior third of the cartilaginous septum, nasal obstruction complete 
Pegler (L. Hemington), case of obstinate headache, accompanied by crusting and muco-pus formation in a man aged forty. in whom the maxillary, sphenoidal, and frontal simuses had been explored without tangible results; for diagnosis. discussion on case of angreiomil of larynx . .338 discussion on case of bony occlusion of left nostril . . . 370 - discussion on case of bleeding polypus of septum . $\quad 372.373$

- discussion on drawing of angeioma of larynx $\quad . \quad 386^{2}$

- discussion on case of maliomant diseatse of tonume 443

- discussion on case of ulceration of nose and trachea . . . 414

- discussion on case of abnormally large Eustachian cartilages projecting into naso-pharynx . . . . . . 666

Perforation (traumatic?) of septum (H. J. Davis) . . . . 326

- (traumatic) of tympanic memliane (H. Macnaughton-.Jones) . 157

Periostitis of temporal bone, complicated by a sub-periosteal mastoid abscess (A. Punnat).

Permewax (W.), discussion on case of fixation of left rocal cord, with pulsating thoracic anewrsm

Petrous hone. cells of : recent investigations on (Mouret) . . 112

Pharyngitis and atrophic rhinitis, with visille pulsation of carotids (J. Donelan)

Pharyngo-larynx : malignant disease, slirles from ease of (C. J. Symonds)

Pharyngotomy (lateral), epithelioma of right arytenoid and adjacent parts removed by (H. Lambert Lack) . - (subhyoid), epithelioma of epiglottis and base of tongue removed by (H. Lambert Latck)

- with resection of hyoid bone as operation of election for exposure of superior orifice of larymx (J. Broeckhatert)

Pharynx. abstracts of literature on adenoid veretations of (C. W. M. Brown) cicatricial diaphagm passing from posterior third of tongue to posterior wall of pharynx (H. Betham Robinson) epithelioma, pharyngo-laryngeal (P. R. W. de Santi) $\cdot \cdot \quad . \quad 286$ infiltration, extensive, with slight ulceration: case for diagnosis

(C. A. Parker) lupus of pharynx and larynx (H. W. Carson).

ulcer. excavated, either tertiary lesion or epithelioma (J. Dundas Grant) (wall of), adhesion between soft palate and posterior wall of (T. K. Hamilton) . $\quad . \quad$. . . . $\quad 241$ arthesion of soft palate to (P. H. Alererombie). tioscussion on intra-cranial complications of mildle-ear suppura-

tion
tina, and measles tina, and measles. . . . . 54t

Phlelitis of sinus, with pyamia (Schmiegelow) $\quad . \quad$. $\quad . \quad 399$

Phthisis (pulmonary): routine inspection of throats of consumptive pationts alvocated (H.S. Barwell) . . . . . . $\quad 649$ 
Physicians and surgeons British), visit to Paris (Section of Laryngology

and Otology) by anastomosis

_ chronic suppuration of the middle ear, basal meningritis later

— intra-cranial abscess, cerebellar; basal meningitis . . 500

PrNkus (Dr.), a new inhaler designed hy Dr. Heryng, of Warsaw 374

Pischel (Kaspar), the use of collodim after nose operations. $\quad .30$

Poli (Professor), discussion on case of fixation of left vocal cord, with pulsating thoracic anewrysm .

Polypus (bleeding) of septum in boy aged nine (E. B. Waggett) : 319

$\begin{array}{lll}\text { Pof nose, with deformity (W. H. Kelson) } & 191\end{array}$

Pons, tumour of. accompanied by pharyngeal and laryngeal nystagmus (Sir F. Semon)

Post-nasal adenoids, specimen removed from man aged fifty-nine $(\vec{H}$.

Lambert Lack) .
Potrer (E. Furniss). case of severe timnitus with (almost complete) loss
of hearing in a man atged twenty-one. - discussion on case of inspiratory dyspnoa, with history of syphilis - case of abnormally large Enstachian cartilages projecting into the naso-pharynx to the extent of interfering with free nasal breathing, in a girl aged sixteen

discussion on case of malignant disease of base of tongue and epiglottis

PowELL (H. FitzGerald), discussion on case of tracheal obstruction epithelioma of palate, tonsil, tongue, and cheek . epithelioma of palate, tonsil, tongue, and cheek $\cdot \cdot \cdot \cdot \cdot \cdot$ discussion on diffinse papilloma of vocal cords $\quad . \quad 5$

- discussion on squamous-celled carcinoma of larynx, first thought

to be tubercular . . . - discussion on case of growth on left vocal cord ${ }^{\circ}$. thoracic aneurysm.

- discussion on case of immobile left cord . discussion on case of abnormally large Eustachian cartilages projecting into naso-pharynx .

Prausnitz: on the treatment of hay fever (alsstract)

Pregnancy (fifth), tuberculosis of larynx commencing during (C. Parker)

Preindlsberger, the removal of tonsillar new growths (abstract) . 109

Pritchard (Urban), discussion on case of fatal leptomeningitis : 71 discussion on resturation of hearing after removal of drum and ossicles by a modification of the radical operation for suppurative ear disease.

ear disease. case of chronic suppurative otorrhoa .

discussion on trammatic perforation of tympanic membiane discussion on cerebellar abscess following acute disease of middle ear discussion on neoplasm of auricle (fibroma?). discussion on case of mastoid fistula

discussion on otitis media hamorrhagica in man with granular kidney and diabetes.

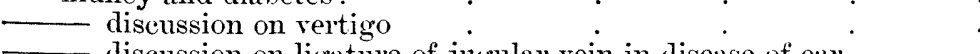

discussion on ligature of jugular vein in disease of ear. logical, and Otological Society for encouragement of special research in diseases of ear, nose, and throat . . . .

Pugnat (Amedée), a case of periostitis of the temporal bone, complicated by a sub-periosteal mastoid abscess (abstract) 
Pugnat (Amedée), note on reflex pareses and affections of speech and writing of auricular origin (abstract) .

Pupil (left) dilatation, associated with complete paralysis of left rocal

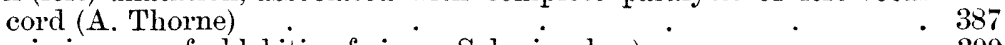

Pyæmia in case of phlebitis of sinus (Schmiegelow) . $\quad$. 399

Pyriform fossa, pharyngeal diverticulum opening into (J. Dundas Grant)

Quinine: "tabloid" quinine, camphor, and aconite . . . 400

RAaron dE LA Sota y LAstra : foreign bodies in the throat (abstrast) . 395

Reflex pareses of auricular origin (Pugnat) . . . . 240

Renoform gauze and wool dressings impregnated with suprarenal extract (F. Koch)

Research work: suggested institution of research work in connection with Otological Society of United Kingdom (T. Barr : presidential address)

Resection (submucous) of deflected nasal septum (Killian's method) (H. Tilley) .

Respiration (nasal) interfered with by abnormally large Eustachian cartilages projecting into naso-pharyons (E. Furniss Potter) .

Respiratory passages, impilution "if pirce of blue chalk in, for three weeks (H. J. Davis) - (upper) : legitimacy of clinical distinction between lupus and ordinary tuberculosis of (E. Escat) . . . .

Respiratory tract (upper), mycosis in, etiology and treatment of (J. Sendziak)

Retropharyngeal abscess of auricular origin ; erosion of carotid; death from hæmorthage (F. Klug)

Reviews: Gubb (Alfred S.). "From Cloud to Sunshine" (1905) Love (J. Kerr), "Diseases of the Ear" (1904) . . . . 50 Wingrave (Wyatt) " Adenoids" (1904) 400

REvor (L.), a case of bilateral paralysis of the recurrent laryngeal nerves (abstract)

Rhinitis (atrophic) and pharyngitis, with visible pulsation of carotids

(J. Donelan) (hypertrophic) of both inferior turbinated bodies (j. Dundas Grant)

section of Laryngology, Rhinology, and Otology at seventythird annual meeting of British Medical Association (1905) announcement of programme.

Rhinoplasty, method of, illustrated by plastic operation of rodent ulcer

on face (A. S. Codman)
Rhinorhea (cerebro-spinal), case apparently recorering spontaneously (P. Watson Williams)

RHodes (J. Edwin), nasal hydrorrhœa (abstract) . . . . 165

Rice (Clarence C.), discussion on abuses in intra-nasal surgery $\quad . \quad 134$

Rrchards (Geo. L.), discussion on diseases of the salivary ducts and glands, and their treatment . discussion on the uses of rubber in the treatment of nasal and three cases of double frontal sinus disease and one of unilateral frontal disease treated by the obliteration method discussion on nose and ear complications in diphtheria, scarlatina, and measles 
RICHARDS (John D.), report of a case of infective sigmoid sinus and jugular thrombosis, complicated by leptomeningitis ; lumbar puncture; sub-dural irrigation; death (abstract)

RICHARDSON (Charles W.), discussion on case of angeio-neurotic odema tiscussion on intra-cranial complications of middle-ear suppuration discussion on nose and ear complications in diphtheria, scarlatina, and measles

Robinson (H. Betham), discussion on mass of malignant glands in neck, swelling of larynx - cicatricial diaphragm due to inherited syphilis passing from the posterior third of the tongue to the posterior wall of the pharynx . - discussion on case of lingual growth

discussion on case of high-arched palate and crowding of teeth . discussion on case of broadening and disfigurement of external nose due to swellings attached to cartilaginous septum soft fibroma on left rocal cord discussion on case of subglottic hyperplasia producing tracheal stenosis discussion on unilateral right abductor paralysis associated with other paralyses on right side .

Rodent ulcer on face: method of rhinoplasty, illustrated by plastic operation for (A. S. Codman)

Röntgen-ray photograph showing pouch when filled with bismuth in ease of pharyngeal diverticulum opening into pyriform fossa $(\boldsymbol{J}$. Dundas Grant)

Roger (B. Franklin), the antitoxin treatment of diphtheria, with a plea for rational dosage in treatment (abstract)

Rubber, uses of, in treatment of nasal and antral diseases (Price Brown)

RUSSELI. (J. S. Risien), vertigo: an address delivered before the Otological Society of the United Kingdom discussion on vertigo (reply)

Safety-pin closer, for use in cesophagus and trachea, exhibition of (H. P. Mosher)

Salivary calculus, simulating angina Ludorici (Wyatt Wingrave)

ducts and glands, diseases of, and their treatment (R. C. Myles)

DE SANTI (Philip R. W.), a case of swelling in the left arytenoid region

in a woman aged thirty-five f woman, aged thirty-five, shown at last meeting, with laryngeal swelling, thought to be tubercular, and microscopic slide showing undoubted squamous-celled carcinoma.

- discussion on case of recurrent ulceration of tonsils associated with lymphadenoma.

man aged sixty: mass of malignant glands in the neck, swelling

of larynx, same side .

discussion on primary sore of tongue

discussion on case of growth on left rocal cord woman, aged thirty-five, with pharrn-w linyngeal epithelioma

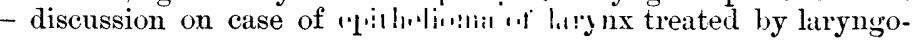
fissure

discussion on case of broadening and disfigurement of external nose, due to swellings attached to cartilaginous septum

- discussion on case of carcinoma of larynx

laryngeal case for diagnosis

discussion on case of bleeding polypus of septum

discussion on case of angeiona of palate

slides from a case of malignant disease of the pharyngo-larynx :

discussion on case of epithelioma of larynx. 
De SANTI (Philip R. W.), woman, aged forty-five, with inspiratory dyspncea, history of syphilis ; for diagnosis - man with malignant disease of the base of the tongue and epislottis: question of operation

- woman with perverted action of the cords, shown at a previous meeting

_... man aged eighty with sarcomatous growth of left nasal cavity; question of operation

and STEWART (Pnrves), a case of unilateral concrenital lesion of the medulla and spinal cord, with brief notes of the pathological changes in the mouth, throat, and ear in a man aged forty-one

Sarcoma of right auricle (giant-celled) (S. Szenes) - of frontal sinus (P. H. Abercrombie)

\section{of nose (J. Price Brown) .}

- of tonsil (J. C. Warren)

Sarcomatous growth of left nasal cavity ; question of operation (P. R. W. de Santi)

Scarlet fever, followed by subacute frontal sinus empyena ( $H$. Tilley) nose and ear complications in scarlatina (J. Mc.Collom) otitis in scarlatina (F. B. Sprague).

SCHadue (Jacob E.), the significance of celema of the pharynx

Schech (Professor Philipp), of Munich (obituary)

SCHIFERs : intubation and tracheotomy (alstract).

Schmiegelow : a case of phlebitis of the sinus with pyamia (abstract).

SCHNEIDER (Karl), treatuent of cesophageal stricture hy injection of thiosinamin (abstract)

Semon (Sir Felix, C.V.O.), discussion on case of incrustations in the trache: epithelioma of the larynx: thyrotomy; recurence; removal of
areater part of the larynx ; recovery .

- discussion on case of swelling in left arytenoid region.

- discussion on case of tratcheal olistruction

- pharyngeal and laryngeal nystagmus in a case of (5) tumour of the pons?

slide from a case of epithelioma of the right vocal cord and neigh-

bourhood in a gentleman aged fifty

discussion on case of epithelioma of palate, tonsil, tongue, and cheek

discussion on case of ulceration of soft palate

inflammatory oxdema of olscure origin affecting the posterior parts of the larynx in a man aged forty-seven

_ _ Iiscussion on tuberculosis of larynx commencing during fifth presnancy .

- discussion on diffuse papilloma of rocal cords

discussion on the late Dr. Whistler's case of growth on right rocal cord.

- discussion on squamous-celled carcinoma, first thought to be tulercular.

- a case of soft filiroma of the larynx and neck removed by operation without opening the cavity of the larynx

discussion on case of epithelioma of larynx treated by laryngo-

fissure discussion on case of carcinoma of larynx $\cdot \dot{ } \cdot \overrightarrow{.}$

discussion on case of high-arched palate and crowding of teeth.

discussion on case of obstinate headache accompanied hy crust.

ing and nuco-pus formation

discussion on case of angeioma of larynx

discussion on unilateral right abductor paralysis associated with

other paralyses on right sirle . 
SExon (Sir Felix, C.V.O.), atomiser for spraying medicated fluid discussion on case of left facial paralysis, with ulceration of oroand naso-pharymx . discussion on case of excavated ulcer of pharynx

- _- discussion on case of epithelioma of larynx . . . $\quad 385,386^{\circ}$

-.___ discussion on ease of inspiratory dyspncea with history of syphilis 390

discussion on case of intrinsic laryngeal neoplasm of left vocal cord

\section{discussion on case of immobile left cord}

discussion on case of malignant disease of hase of tongue and epigrlottis

SExDzrak (John), the etiology and treatment of mycosis occurring in the upper respiratory tract.

Septotome, new. exhilition of (W. A. Wells)

Septum (memhranous) in interior of lateral sinus (A. H. Cheatle)

Septum-cutter, new, exhibition of (W. L. Ballenger) .

Secquestrum of wall of meatus (Ferran)

Serum (anti-thyroidine. Moebius's), treatment of Basedow's disease with (Hempel) (Thienger)

treatment of hay fever $(H$. W. Loel. $)$

SEWELL (Lindley), an analysis of 5000 cases of ear disease, with special reference to their etiology

Shambaugh (George E.), the distribution of blood-vessels in the labyrinth of the ear of the sheep and the calf (abstract)

Sheep, distribution of hood-vessels in labyrinth of ear of (G. E. Shambaugh)

Shoe-button obstructing left hronchus (W. B. Thistle)

SiEBert (A.), a contrihution to diphtheria in early life (abstract)

Simoons (Channing C.) and CoBB (Farrar), the results in cases of cancer of the tonsils. tongue. and jaws, operated on at the Massachusetts General Hospital during the eight years from January 1, 189:2, to January 1, 1900 (abstract)

Stmpson (W. K.), discussion on aluses in intra-nasal surgery .

Singer, combined functional and organic paresis of laryux in a (G. C. Catheart) .

Sinus suppuration multiple (C. J. Brady)

- (cavernous). thrombo-phlebitis, of otitic origin (V. Delsaux)

(carernous). thrombo-phlebitis, of otitic origin
(frontal), applied anatomy of (H. P. Mosher).

- - disease, long-standing (H. H. Curtis)

three cases of double frontal sinus disease and one of unilateral frontal disease treated by the obliteration method

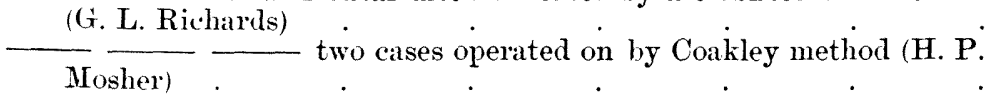

Mosher) empyema of (F. C. Cobb) : subacute, following scarlet fever $(\mathrm{H}$. Tilley) lympho-sarcoma of (A. Wylie, P. H. A bercrombie) new operation and instruments for draining (E. Fletcher

Ingals)

bone (R. H. Scanes Spicer) with subacute osteomyelitis of frontal

- _ sarcoma of (P. H. A bererombie) $\quad 47$ 
Sinus (sigmoid). infectire sigmoid sinus and jugular thrombosis, complicated by lepto-meningitis ; lumbar puncture; subdural irrigation; death (J. D. Richards)

(J. F. McKernon) thrombosis: symptomatology, diagnosis, and treatment

(sphenoidal) : empyema of right sphenoidal cavity and posterior ethmoidal cells associated with complete occlusion of right posterior naris (R. H. Craig) .

- combined disease of maxillary antrum. ethmoid lahy: rinth, and sphenoid sinus, operation by maxillary route for (J. P. Berens)

Sinuses, anatomy of, plates illustrating

(frontal), lympho-sarcoma of (P. H. Abercrombie)

(left frontal and ethmoidal), combined empyema of (R.H. (raig) - (maxillary, sphenoidal. and frontal) explored without tangible results in case of obstinate headache accompanied by crusting and muco-pus formation (L. H. Pegler)

- (sigmoid and lateral), thrombosis of (infective), after acute mas. toiditis (A. Knapp) .

Simusitis, intra-cranial complications of ( $\mathrm{V}$. Delsaux)

(frontal) : diagnosis, treatment, and results (C. G. Coakley) (maxillary). radical operation performed for (Chichele Nourse) . (prolonged acute), alveolar lesions in (Jacques).

(sphenoidal and posterior ethmoidal), case cured (P. Watson Williams)

Skin-grafting (E. B. Wagrgett)

Skull (hase of fracture, case followed by disease of ear (Mr Collier)

SMiтh (Maynard), report on Dr. Scanes Spicer's case of sulacute osteomyelitis of frontal bone with empyema of right frontal sinus

report on wrowth in Dr. Scanes Spicer"s case of intrinsic laryngeal neoplasm of left vocal cord in a man aged serenty-three .

Sмгтн (S. MacCuen), meningitis; its symptomatology, diagnosis, and treatment, with report of a case discussion on nose and ear complications in diphtheria, scarla. tina, and measles

- discussion on indications for operation in acute mastodilitis

SMURThWAITE (Hugh), paintings in oil illustrating diseases of the throat and larynx

- discussion on intra-nasal disease as a determining factor in pro-

duction of laryngeal and pulnonary affections . . . discussion on case of tixation of left rocal cord. with pulsating thoracic aneurysm .

- discussion on case of nasal tuberculosis

_ epithelioma of larynx in a man aged fifty-five discussion on case of extensive infiltration of pharynx

- discussion on the treatment of laryngeal tuberculosis .

Sмутн (Herbert), discussion on serum treatment of hay fever .

Solly (S. E.), case of carcinoma of the larynx

SonDERMAN : a new method for the diagnosis and treatment of nasal

disease (abstract) ${ }_{\text {nasal suppuration in children, and its treatment by aspiration }}$ (alistract) .

(1) suction as a therapentical measure in diseases of the ear;

(2) a new masseur for the ear (ahstract)

Sound : transmission in middle ear and reception in labyrinth (Mongardi:

"Considerations et analocies physigues")

Speech, affections, of aluricular origin (Pugnat)

SPEACER (W. G.), discussion on case of vilceration of soft palate discussion on case of inflammatory adema of obscure origin, affecting posterior parts of larynx 
SpICER (Frederick), discussion on restoration of hearing after removal of drum and ossicles by a modification of the radical operation for

suppurative ear disease for cords (case shown hy Mr. C. Fox).

SPICER (R. H. Scanes), discussion on case of tracheal obstruction discussion on intra-nasal disease as a determining factor in pro. duction of laryngeal and pulmonary affections.

discussion on tuberculosis of larynx commencing during fifth pregnancy. cord - discussion on squamous-celled carcinoma of larynx, first thought

to be tubercular

- discussion on fixation of left rocal cord

frontal sinus

intrinsic laryngeal neoplasim of left rocal cord. in a man aged seventy-three

discussion on case of probable malignaint disease of maxillary intrum

- discussion on case of malignant disease of base of tongue and epiglottis .

discussion on case of perverted action of the cords

Spinal cord : unilateral congenital lesion of the medulla and spinal cord; patholocrical changes in mouth, throat, and ear (P. R. W. de Santi and P. Stewart)

Spine of Henle, constancy and varieties of (P. Macleod Yearsley)

Splint (nasal), exhibition of (H. P. Mosher)

SPraguE (Frank B.), case of tympano-mastoid exenteration, showing healing of cavity by blood-clot and of wound by subcutaneous silk suture

- scarlatinal otitis .

Spray-heater, electrical .

Staphylococcus causing croup (F. P. Anzinger)

Stenosis norompan

"f lallils: ir.aim.n: by tracheotomy (StC. Thomson). of trachea from adenomata in thyroid (M. Collier) produced by subglottic hyperplasia (H. Tilley).

Stevani (R.), an insufficiently known disease of nasal origin (ahstract).

STEWARD (F. J.), case of paralysis of left rocal cord caused by localised tumour of thyroid gland (malignant :)

- discussion on tuberculosis of larynx commencing duing fifth pregnancy .

discussion on squamous-celled carcinoma, first thought to be tubercular .

- recurrent ulceration of tomsils associated with lymph-adenoma in a woman aged sixty-four.

Stewart (Purves), and DE SANTi (P. R. W. ), a case of unilateral congenital lesion of the medulla and spinal cord. with brief notes of the pathological changes in the mouth. throat, and ear, in a man aged forty-nine

StIRLING (W.), demonstration on otocysts and the ampullary apparatus

Stomach, diseases of, in relation to affections of the month, nose, and throat (R. Lery)

StUART-Low (W.), discussion on salirary caleulus simulating angina Ludovici 
Stccky (J. A.), discussion on the relation of diseases of the stomach to affections of the mouth, nose, and throat

- exhilition of improved head-lamp

discussion on nose and ear complications in diphtheria, scarla-

tina, and measles discussion on indications for operation in acute mastoilitis

Subglottic region, forein body in (Gosteau)

"Suction" as a therapentical measure in diseases of the ear (Sondermann)

Suppuration of frontal sinus, donble, eured by radical operation (E. B. Wargett)

of lahyrinth, acute, supervening in ase of chronic suppurative otrorhar (H. Tilley).

- operation in two cases; special reference to path of infection (W. Millisam)

$166^{2}$ of middle ear, acute (editorial) hysteria following (S. Szenes)

(W. Milligan)

\section{(E. B. Wagigett)}

(T. Hulbard)

- (nasil) in children; treatment by aspiration (Sondermann) .

Suppurations in accesary cavities of nose: do they bring about narrowing of field of rision : (Henrici and Hatfiner)

Suprarenal extract, dressings impresnated with (renoform gatuze and wool) (F. Koch)

Supra-tonsillar fossa, pedunculated tumour growing from (j. Dundas Grant)

Surgeons and physicians (British), visit to Paris (Section of Larynsology and Otology)

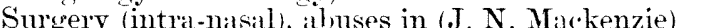

Sotherlaxd (G. A.), discussion on nasid obstruction and mouth. lireathing

Swelling in left arytenoid region (P. R. W. de Santi). . . 204

- (post-pharyngeal) (F. W. Bennett) . . . . 10:

Swellings, tense, hilateral, non-rascular, attached to anterior third of cartilasinous septum. causing broadening and disfipurement of external nose and complete nasal obstruction (L. H. Pegler).

Srme (W. S.), a case of congenital word-deafness discussion on the treatment of larynoreal tuberculosis:

Symonds (C. J.), discussion on intra-nasal disease ats a determining factor in production of laryngeal and pulmonary affections

discussion on case of recurrent ulceration of tonsils associated with lymphadenoma

Society of London.

Celebration in relation to Laryngological 
Srmonds (C. J.), discussion on unilateral right abductor paralysis associated with other paralyses on right sicle

PAGE a case seren years after complete extirpation of the larynx $\quad .367$ papilloma of the larynx . . . . . 367 discussion on case of hony occlusion of left nostril . . . 3ti9 discussion on case of angeioma of palate

discussion on subacute osteomyelitis of frontal hone. with empyema of right frontal sinus. exhibition of case of total extirpation of the larynx in a man . 381 - discussion on case of natsal tuberculosis . . 382 discussion on case of new wowth in right maxillary antrum of hoy aged ten discussion on case of faucial eruption

discussion on case of prohalle malignant disease of maxillary antrum

- discussion on caise of ahmormally larege Eustachian cartilages projecting into $1,1, \cdots, \cdots, 1,1,1,1$.

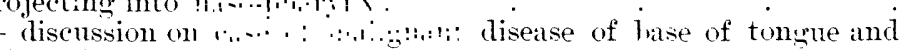
epiglottis.

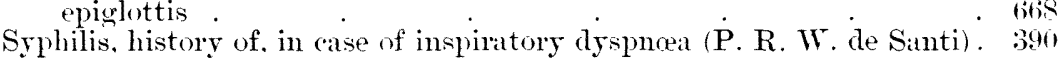
manifestations in upper air-passiaps. symposimm on of larynx. stenosis. acute syphilitic: cure ly injection of biniolide of mercury (Malatosse) mosual case requirine tracheotomy (C. F. Theisen) - of nose and accessory simuses (J. E. Logan) .

- probable syphilitic origin of sulgettic hyperplasia producing tracheal stenosis (H. Tilley) . syphilitic manifestations in larrnx and trachea (F. B. Packard). (congenital). cicatricial diaphram due to inheriterl syphilis passing from posterior third of tongue to posterior wall of pharynx

(H. Betham Robinson) (primary), case of primary sore of tongue (H. Tilley) .

(tertiary), excarated ulcer of pharymx with punched-ont appearance of tertiary lesion (J. Dumclas Grant)

Syringe for intra-laryngeal injections (Wyatt Wingrave)

richt anich free in the right external auditory meatus: (4) a case of hysteria. following acute middle-ear suppuration

"Tabloid" quinine, camphor, and aconite.

Teeth (crowding of), due to nasal ohstruction (H. Lambert Lack)

Temporal hone, periostitis of, complicated by a sub-periosteal mastoid abscess (A. Pugnat).

Temporal bones : series of 250 sectioned reitically through antrum and mastoid process (A. H. Cheatle) (three) from cases of chronic middle-ear suppuration iA. Logan Turner)

Temporo-sphenoidal lobe of brain, abscess in. following an acute otitis media (T. H. Halsted)

Theisen (Clement F.), the etiology and diagnosis of ozima and its relation to pulmonary tuherculosis (ahstract)

- an unusual case of laryngeal syphilis requiring tracheotomy

Therapentic prension on serum treatment of hay fever.

$296.399 .507,620$ $3.3 .398,4.1$

Thienger : some observations on Moebius anti-thrionime (abstract) . 11:

Thiosianin, treatment of esophageal stricture lis. injection of (K. Schneider) 
Thistue (W. B.), obstruction of left bronchus by a shoe-button

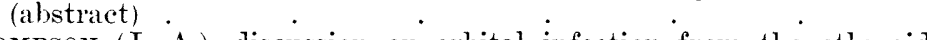

Thompsos (J. A.). discussion on orbital infection from the ethmoid cells with spontaneous opening of inner angle of the orbit

Thomson (StClair), epithelioma of larynx; laryngo-fissure; no recurrence after six months

- tracheotomy for laryngeal stenosis ; marked improvement; diagnosis : tuberculosis, lupus, or congenital syphilis

- discussion on case of swelling in left arytenoid region.

discussion on case of pharyngeal and laryngeal nystagmus

discussion on case of ulceration of soft palate

discussion on intra-nasal disease as a determining factor in pro-

duction of laryngeal and pulmonary affections.

discussion on diffuse papilloma of rocal cords

discussion on case of extensive ulceration of nasal septum

discussion on case of growth on left vocal cord

epithelioma of the larynx in a man aged forty-nine; laryngo-

fissure eight months ago; no recurrence

primary lupus of larynx (quite healed) and pharynx (nearly

healed) in a woman aged twenty-two, with drawings of original condition

discussion on case of obstinate headache accompanied by crusting

and muco-pus formation

- discussion on soft fibroma on left vocal cord .

discussion on case of angeioma of larynx

discussion on case shown seven years after complete extirpation

of larynx

discussion on case of epithelioma of larynx.

drawing of angeioma of larynx

discussion on case of post-nasal adenoids

discussion on case of inspiratory dyspncea with history of

syphilis discussion on case of extensive infiltration of pharynx .

discussion on the treatment of laryngeal tuberculosis.

Thorax : see Aneurysm (thoracic).

THORNE (Atwood). discussion on growth of auricle .

discussion on laryngeal case for diagnosis

girl ared seventeen: complete paralysis of the left vocal cord, associated with dilatation of the left pupil, mitral stenosis, and enlargement of the left auricle

discussion on case of inspiratory dyspnœa, with history of syphilis

discussion on prevalence of adenoids

discussion on the treatment of laryngeal tuberculosis .

- and LUNN (J. R.), case of epithelioma of the nose (shown at the

January meeting (1904); patient, macroscopic and microscopic specimens and photographs.

Throat (diseases), diseases of stomach in relation to (R. Levy) paintinus in oil illustrating (H. Smurthwaite). prizes offered for special research in, by senior mem-

bers of American Laryngological, Rhinological, and Otological

Society foreign bodies in (Ramon de la Sota y Lastra) operations upon, fatal results of (F. R. Packard)

pathological changes in, in case of unilateral congenital lesion

of medulla and spinal cord (P. R. W. de Santi and P. Stewart)

Throats of consumptive patients, routine inspection advocated $(H . S$. Barwell)

Thrombo-phlebitis of cavernous sinus of otitic origin (V. Delsaux) 
Thrombosis of sigmoid sinus : symptomatology, diagnosis, and treatment (J. F. McKernon)

Knapp) of sigmoid and lateral sinuses after acte mastoidis (A. tumour of. malignant (?), causing paralysis of left vocal cord

(F. J. Steward)

gland. treatment of Basedow's disease with anti-thyroidine serum (Moelius) (Hempel) (Thienger).

Thyrotomy for epithelioma of larynx (Sir Felix Semon)
papilloma of larynx : high tracheotomy ; thyrotomy ; recovery

(R. H. Craig)

Tiluey (Herbert), discussion on case of tumour of nose

- case of lympho-sarcoma of the tonsil in which great benefit had heen derived from arsenic .

- case of submucous resection of a deflected nasal septum (Killian's method)

child

subacute frontal sinus empyema following scarlet fever in a

child supervention of acute labyrinthine suppuration in a case of

chronic suppurative otorrhœa.

_ - case of tracheal obstruction of uncertain origin and nature

discussion on case of pharrnenal and laryngeal nystagmus .

- discussion on case if intiammitl.ry œdema of obscure origin

affecting posterior parts of larynx .

- discussion on intra-nasal disease as a determining factor in pro-

duction of laryngeal and pulmonary affections.
discussion on tuberculosis of larynx commencing during fifth

pregnancy.

priscussion on case of recurrent ulceration of tonsils associated

with lymphadenoma

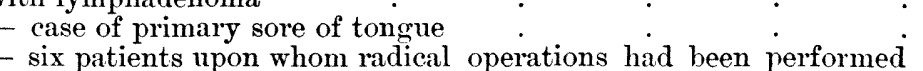

for the cure of chronic empyemata of the frontal and other nasal

accessory sinuses discussion on case of obstinate headache accompanied by crusting and muco-pus formation

- subglottic hyperplasia, producing tracheal stenosis, probably of syphilitic origin

— unilateral right abductor paralysis, associated with paralyses of right half of soft palate and pharynx, right sterno-mastoid. upper fibres of right trapezius, ptosis of the right upper eyelid. and contracted pupil

- discussion on case of bony occlusion of left nostril :

Tinnitus and vertigo, removal of part of cochlea, external wall of vestibule, and external semicircular canal for relief of ( $R$. Lake) .

- aurium and hallucinations of hearing: or relation of ear disease to auditory hallucinations of the insane (W. S. Bryant) - (severe) with almost complete loss of hearing (E. F. Potter)

ToD (Hunter F.), a case of hernia cerebri encephalitis

\section{1}

112

48 
ToD (Hunter F.), discussion on removal of part of cochlea, external wall of vestibule, and external semicircular canal for relief of tinnitus and vertigo

case of mastoid fistula for opinion as to treatment . - discussion on vertigo

Tongue, cancer of. results of cases operated on in Massachusetts General Hospital, 189.-1900 (F. Cobb and C. C. Simmons)

- cicatricial diaphragm passing from posterior third of tongne to posterior wall of pharynx (H. Betham Robinson)

- epithelioma of epiglottis and hase of tongue removed liy subhyoid pharyngotomy (H. Lambert Lack) . - fibroma of (specimen) (W. H. Kelson) growth on, in man aged sixty (W. H. Kelson) $\quad . \quad$. $\quad .3$ lenkoplakia of (P. H. Abercrombie). $\quad . \quad$. $\quad . \quad 198$

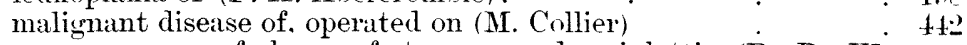

de Santi) . primary sore of $(\dot{H}$. Tilley) $\cdot \cdot \cdot 66$. primary sore of (H. Tilley)

Tonsil : epitheliona of palate, tonsil, tongue. and cheek (H. FitzGerald Powell)

Powell)
lymphosarcoma of, greatly benefited by arsenic (H. Tilley)
new growths of, removal (Preindlsberger)

- new growths of, removal (Preindlsberger)

- tumour of (V. Wyatt Wingrave)

PAGI

201

Tonsils (cancer of), results of cases operated on at Massatchusetts General

Hospital (189:-1900) (F. Cobb and C. C. Simmons)

- (ulceration, recurrent, of), associated with lymphadenoma (F. J. Steward)

Torticollis, following removal of adenoids (Ferreri) .

Trachea : abstracts of literature on

$$
\text { and nose. ulceration of (W. H. Kelson) }
$$
incrustations in (E. Law) .

$$
\text { accompanied at times by stenosis (E. Law) }
$$

Killian's inspection of, demonstration (H. P. Mosher).

obstruction in, origin and nature uncertain (H. Tilley).

safety-pin closer for use in, exhibition of (H. P. Mosher)

stenosis of. from adenomata in thyroid (M. Collier) syphilitic produced by subglot tic hyperplasia (H. Tilley).

followed by laryngo-fissure in removal of fibroma of larynx (T. J.

Harris) for laryngeal stenosis (StC. Thomson)
(high) and thyrotomy for papilloma of larynx : recovery (R. H. Craig)
in laryngeal syphilis (C. F. Theisen)
Trequired in cases of croup due to staphylococens (F. P. Anzinger)
Trans-maxillary-nasal passage (" De la voie trans-maxillo-nasale," etc.)
(Duverger).

Trauma and septal deformity, causing almost complete bony occlusion of left nostril (J. Donelan)

Traumatic lesion of larynx (J. Dundas Grant)

- perforation of tympanic membrane (H. Macnaughton-Jones) 


\section{Index.}

Tuberculosis of larynx in a woman, commencing during fifth pregnancy (C. Parker)

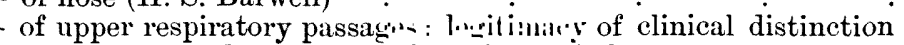

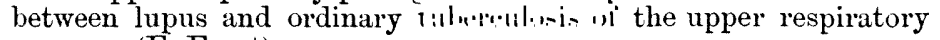
passages (E. Escat) .

of faucial tonsil (V. Wyatt Wingrave)

(primary), supposed, of pharyngeal tonsil (D. M. Barstow)

(pulmonary), ozæna in relation to (C. F. Theisen)

swelling of larynx, first thought to be tubercular, but shown by

microscopic slide undoubted squamous-celled carcinoma (P. R. W. de Santi) .

Tuberculous laryngitis, treatment; choice of method (H. S. Barwell)

Tumour (endothelioma) of external auditory meatus (E. B. Waggett)

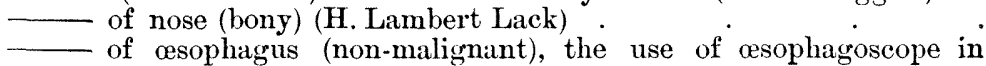

(L. Harmer)

of pons, accompanied by pharyngeal and laryngeal nystagmus

(Sir F. Semon)

(F. J. Steward)

of tonsil (V. Wyatt Wingrave)

(pedunculated), probably cystic, growing from supra-tonsillar fossia (J. Dundas Grant)

T'urbinate (lower), cauterisation of, ultimate results (j. L. Goodale)

Turbinated bodies, hypertrophic rhinitis involving both inferior turbinated bodies (D. Grant)

Turbinated body (middle), sessile outgrowth on septum simulating (J. Dundas Grant)

Turbine, oto-masseur driven by (R. Lake) .

TURner (A. Logan), discussion on malignant disease of the upper air-

passages a contribution to the pathology of bone cysts in the accessory sinuses of the nose (abstract).

discussion on removal of part of cochlea, external wall of vestibule, and external semicircular canal for relief of tinnitus and vertigo tion

TURNER (J. G.), discussion on case of high-arched palate and crowding of teeth

Tympanic cavity, inflammation, acute septic (so-called otitis media) treat-

ment (A. H. Young and W. Milligan)
Tympanic membrane: collodion in relaxation of (F. Chavanne)

Tympanic membrane: collodion in relaxation of (F. Chavanne) cysts of (Haug, Rud)

emphysema (:) of (A. L. Whitehead)

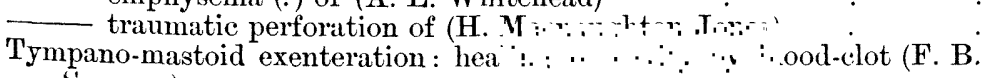

Sprague)
Tympanum : restoration of hearing. after removing ossicles and drum by
modification of modification of radical mastoid operation (C. Heath)

- vascular intra-tympanic growth, probably an aneurysm by anastomosis (T. H. Pinder) 
\begin{tabular}{l} 
Typhoid fever, laryngeal complications in (C. Jackson) \\
otitis media (acute purulent) in ; case, with autopsy (E. W. Day). \\
\hline 551
\end{tabular}

Ulcer of the nose (primary) (Wyatt Wingrave) _ . . . 41

of pharynx, excavated, either tertiary lesion or epithelioma

(J. Dundas Grant)

of tongue (J. Dundas Grant)

378

101

Ulceration of nasal septum (extensive): case for diagnosis (F. W. Bennett) 282

of nose and trachea (W. H. Kelson). 4.4

of oro- and naso-pharynx, with left facial paralysis (H. J. Davis) 377

of palate: case for diagnosis (V. Wyatt Wingrave) . . 19:

of soft palate : case for diagnosis (F. H. Westmacott). 21:

of tonsil and palate (W. H. Kelson). . . 392

- of tonsils (recurrent) associated with lymphadenoma (F. J.

Steward) . . . . . . . 27

slight, accompanying extensive infiltration of pharynx (C. A.

Parker)

"Urticaria of the drum" (L. A. Lawrence).

Uvula : lupus of larynx and uvula (H. S. Barwell) :

Vaseline (medicated fluid), atomiser for spraying (Sir F. Semon) . 373

Ventricle of Morgagni, eversion or prolapse of (V. Delsaux) . $\quad 397$

Vertigo (amral) (editorial) . . . . . 402

- Sir V. Horsley) . $\quad . \quad 403$

- (J. S. Risien Russell) : : : : : . 409

— Ménière's disease : clinical and experimental inquiry (W.

Milligan) Mán

Ménière symptom complex (W. A. Lecompte)

and tinnitus, removal of part of cochlea, external wall of

vestibule, and external semicircular canal for relief of (R. Lake) .

Vestibule, removal of external wall of, and of part of cochlea, and of

external semicircular canal for tinnitus and vertigo (R. Lake) .257

Victor Electrical Air-compressor . $\quad . \quad$. . . 296

De Vilbiss Nebulizer . . . . . . . . . 296

VinRaCe (Dennis), discussion on case of primary ulcer of the nose $\quad{ }_{42}$ - remarks on Presidential Address by Mr. Chichele Nourse at

General Meeting of British Laryngological, Rhinological, and Oto-

logical Association (January 13, 1905) . . . . 191 case of ulceration of palate for diagnosis . $\quad 192$

discussion on case of excision of superior maxilla for epithelioma

of antrum in a boy . $\quad . \quad$. $\quad . \quad 3 \quad . \quad 340$

discussion on case of perforation of septum : $\quad . \quad 327$

- discussion on nasal obstruction and mouth-breathing : $\quad \cdot 348$

\begin{tabular}{ll}
\hline discussion on nasal obstruction and mouth-breathing & $\cdot$ \\
\hline
\end{tabular}

- discussion on prevalence of adenoids $\quad . \quad 5450$

VIOLLET: lupus and epithelioma in an old man (abstract) $\quad: \quad 535$

Vision (field of), do suppurations in accessory cavities of nose bring about narrowing of ? (Henrici and Haeffner) .166

Visit of British physicians and surgeons to Paris (Section of Laryngrology and Otology)

Vocal cord (left), fibroma (soft) on (H. Betham Robinson) • $\quad \cdot 353$

- . $\quad . \quad 5 \quad . \quad 276$

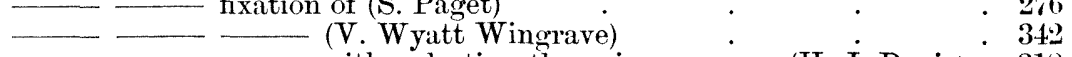

- - with pulsating thoracic aneurysm (H. J. Davis) ${ }_{318}$

\begin{tabular}{l}
-1 crowth on, with slight hoarseness of voice (S. Paget) \\
\hline immobility of (W. H. Kelson)
\end{tabular}

\begin{tabular}{c} 
intrinsic laryngeil neoplasm of (R. H. Scanes Spicer) \\
\hline
\end{tabular} 
Vocal cord (left), paralysis of cansed ly localised tumour of thyroid gland; malignant (:) (F. J. Steward) . _ _ - complete, associated with dilatation of left pupil, mitral stenosis and enlargement of left auricle (A. Thorne) Nomrse) following operation for adenoids (W. Chichele (right), epithelioma (Sir F. Semon). perverted action of $(\mathbf{P} . \mathbf{R}$. W. de Santi)

WAGGETT (E. B.), tumour (endothelioma) of external auditory meatus .

- discussion on hernia cerehri et cerelselli, the result of acute encephalitis

- discussion on the late $\mathrm{Dr}$. Whistler's case of growth on right vocal cord

discussion on squamous-celled carcinoma, first thought to be

tubercular.

- discussion on case of perforation of septum

discussion on case of obstinate headache accompanied by crusting and muco-pus formation

case of double frontal sinus suppuration, in young man, cured by radical operation

- bleeding polypus of septum in a boy acred nine

discussion on case of angeioma of palate

- discussion on vertigo

the lines of treatment in preventing acute middle-ear suppuration

from becoming chronic

WALLACE (J

WARREN (J. Collins), sarcoma of the tonsil (abstract)

Weichselbaum, Diplococcus intracellularis of, causing acute otitis media suppurativa in two cases ( $G$. Bacom)

WeLLS (Walter A.), exhibition of new septotome sinuses

West (C. E.). discussion on cerebellar abscess following acute disease of middle ear .

discussion on removal of part of cochlea, external wall of restibule, and external semicircular canal for relief of timnitus and vertigo

West (Samuel), introductory paper of discission on intra-nasal disease' as a determining factor in the production of laryngeal and pulmonary affections (spasmodic and catirrhal)

Westerman (Arthur), histological changes brought ahout in the nasal mucous membrane by the application of the galvano-cautery : a study of the process of healing in the mucous membrane of the nose after a portion has been destroyed or injured

WESTMACOTT (F. H.), discussion on case of epithelioma of palate tonsil, tongue, and cheek ulceration of soft palate for diagmosis tubercular.

- discussion on case of perforation of septum ase of hich-arched palate and crowding of teeth . - discussion on case of olsstinate headache, accompanied by crusting and muco-pus formation 
WhIsTuER (the late Dr.), growth on right vocal cord removed hy him twenty-two years ago, with present hoarseness, cough, pain, and bloody expectoration (E. Law)

WhIteHEAD (A. L.), a case of acute cerebral abscess

- discussion on supervention of acute labyrinthine suppuration in case of chronic suppurative otorthœa ear

- sketch and notes of a case of emphysema (?) of the membrana tympani discussion on case of mastoid fistula

discussion on ligature of jugular vein in disease of ear

WiEner (Alfred), some mooted points in the treatment of protracted cases of acute middle-ear diseases and their complications (abstract)

WIGG (James), discussion on nasal obstruction and mouth-breathing discussion on prevalence of adenoids

WILkIN (Griffin C.), the prevalence of adenoids

Williams (P. Watson), discussion on case of epithelioma of palate, tonsil, tongue, and cheek

discussion on case of ulceration of soft palate

- discussion on intra-nasal disease as a determining factor in production of laryngeal and pulmonary affections

. discussion on case of fixation of left vocal cord, with pulsatinis

thoracic aneurysm

- case of cerebro-spinal rhinorrhœa which had apparently recovered spontaneously

case of sphenoidal and posterior ethmoidal sinusitis cured

diphtheria in reference to the infectivity and notification of latent

forms

discussion on the treatment of laryngeal tuberculosis

Wingrave (V. Wyatt), case of salivary calculus simulating angina

Ludovici in a male aged thirty
case of epithelioma of the laryngo-pharynx wearing a Jacques; asophageal tube

- case of primary ulcer of the nose

- case of cystic disease of the antrum .

microscopic specimens of $(a)$ tuberculosis of the fancial tonsil;

(b) tuberculosis of the cervical lymph-glands; $(c)$ epithelioma of the

laryngo-pharynx.

a syringe for intri-larrngeal injections

case of tumour of the tomsil

case of ulceration of palate for diagnosis

discussion on case of nasal polypus, with deformit

discussion on tertiary syphilis of nose associated with epiphora.

discussion on case of paralysis of left vocal cord following opera-

tion for adenoids

- microscopic report un Dr. P. H. Abercrombie's case of lympho-

sarcoma of frontal sinuses

- discussion on angeiolipoma (?) of right auricle and meatus

neoplasm of auricle (fibroma?)

malformation of auricle in an infant aged three months

discussion on case of excision of superior maxilla for epithelioma

of antrum in a boy.

case of fixation of the left vocal cord in a youth aged fifteen

case of growth of auricle in a female aged twenty-two .

microscopical specimen; epitheliona of larynx, from a case under

the care of Dr. Lodge

microscopical specimen; dermoid cyst of neck, from a case under

the care of $\mathrm{Mr}$. Nourse

- discussion on nasal obstruction and mouth-breathing . 
Wingrave (V. Wyatt), “ Adenoids: " (1904), review - appointed custodian of collection of microscopic specimens to be formed hy British Laryngological, Rhinological and Otological Association

discussion on case of epithelioma of larynx report on Mr. Chichele Nourse's laryngeal case for diagnosis discussion on prevalence of adenoids

Wire cheek and lip retractor, exhibition of (H. P. Mosher)

Wool and gauze dressings (renoform) impregnated with supra-renal extract (F. Koch)

Word-deafness (congenital) (W. S. Syme)

Writing, affections, of auricular origin (Pugnat) $\quad . \quad 5 . \quad 240$

WYLIE (Andrew), case of epithelioma of the auricle . . $\quad 41$ case of growth (papilloma) in the larynx, under treatment by galvano-cautery

case of lympho-sarcoma of the frontal sinus shown by Dr. P. H.

Abercrombie (previously shown by Dr. Wylie) .

Yearsiey (P. Macleod), discussion on demonstration of specimens by Dr. A. A. Gray to show membranous labyrinth in man and lower

animals discussion on restoration of hearing after removal of drum and ossicles by a modification of the radical operation for suppurative

ear disease. $\quad . \quad . \quad . \quad 137,145$

__ discussion on deafness following mumps $\quad . \quad \vdots \quad 154$

- discussion on traumatic perforation of tympanic membrane $\quad 159$

\begin{tabular}{ll} 
discussion on emphysema (?) of membrana tympani & $\cdot$ \\
\hline
\end{tabular}

- discussion on neoplasm of auricle (fibroma?) . $: 263$

The constancy and the varieties of the spine of Henle (abstract). 351

Yost (A. K.), the history of the antitoxin treatment of diphtheria, with the reasons for its success (abstract)

Young (A. H.) and MrLligan (W. H.), the continuity of the several cavities of the middle ear, with observations on their development, and on the treatment of acute septic inflammation of the tympanic cavity (so-called otitis media).

Zygomatic cells extensively involved in case of double mastoiditis (W. P. Brandegee) 